\title{
All Together Now: Using Principles of GrouP DYNAMICS TO TRAIN BETTER JURORS
}

\author{
SARA GORDON*
}

\begin{abstract}
We ask juries to make important decisions that have a profound impact on people's lives. We leave these decisions in the hands of groups of laypeople because we hope that the diverse range of experiences and knowledge in the group will lead to more thoughtful and informed decisionmaking. ${ }^{1}$ Studies suggest that diverse groups of jurors have different perspectives on evidence, engage in more thorough debate, and more closely evaluate facts. ${ }^{2}$ At the same time, there are a variety of problems associated with group decisionmaking, from the loss of individual motivation in group settings, to the vulnerability of groups, to various cognitive biases and errors. ${ }^{3}$ Moreover, jurors are often at a disadvantage because most of them have never served on a jury and many of them have never worked with a group to reach a decision about a complex problem. ${ }^{4}$ Compounding these issues, jurors are not typically given instructions or training on working in a group or on effective decisionmaking strategies.

Although there is extensive literature examining juries and jury deliberations, this Article is the first to consider all of the major scientific studies that examine training in group decisionmaking and apply them to jury decisionmaking. Many studies have examined group processes and group deliberations in the fields of social psychology, organizational psychology, business administration, advertising, and a variety of related areas. ${ }^{5}$ Moreover, countless studies examine group decisionmaking and recommend the use of training to improve group performance. $^{6}$ Yet almost none of this interdisciplinary knowledge of group
\end{abstract}

* Associate Professor of Law, William S. Boyd School of Law, University of Nevada, Las Vegas. Thank you to Linda Berger, Linda Edwards, Michael Higdon, Elizabeth Pollman, and Kathy Stanchi for their helpful comments and suggestions. Thanks also to the editors of the Indiana Law Review for their valuable editorial suggestions and to Chad Schatzle for his excellent research assistance.

1. David D. Henningsen et al., Role of Social Loafing in Predeliberation Decision Making, 4 Group Dynamics: TheOry, Res., \& Practice 168 (2000).

2. NeIL Vidmar \& VALERIE P. HANS, AmericAn Juries 74 (2007).

3. Norbert L. Kerr et al., Bias in Judgment: Comparing Individuals and Groups, 103 PSYCHOL. REV. 687, 713 (1996).

4. Henningsen et al., supra note 1.

5. J. Richard Hackman, Learning More By Crossing Levels: Evidence From Airplanes, Hospitals, and Orchestras, 24 J. ORG. BehaV. 905 (2003); Steven A. Murphy \& Michael L. McIntyre, Board of Director Performance: A Group Dynamics Perspective, 7 CORP. GOVERNANCE 209, 213 (2007); Gwen M. Wittenbaum \& Richard L. Moreland, Small-Group Research in Social Psychology: Topics and Trends over Time, 2 Soc. \& PERSONALITy Psychol. Compass 187, 187 (2008).

6. Herman Aguinis \& Kurt Kraiger, Benefits of Training and Development for Individuals

http://dx.doi.org/10.18060/4806.0002 
dynamics and the efficacy of training on group performance has been applied to one of the most fundamental group decisionmaking bodies - the jury. We can use this literature to create effective juror training procedures and give jurors strategies to more effectively deliberate and reach better group decisions.

"Gettin' good players is easy. Gettin' 'em to play together is the hard part." -Casey Stengel ${ }^{7}$

\section{INTRODUCTION}

On a college campus, student volunteers were interviewed to discuss "some of the problems involved in life at an urban university." "Some of the volunteers completed the written interview questions alone in a room, while others completed the questions in groups of three. ${ }^{9}$ As they were answering questions, smoke started to drift through a wall vent. ${ }^{10}$ When alone in the room, it took an average of two minutes for the volunteers to stop answering questions and report the smoke and seventy-five percent of them reported the smoke before six minutes had elapsed. ${ }^{11}$ When in groups, only one of the twenty-four volunteers reported the smoke within the first four minutes "before the room got noticeably unpleasant," and only three reported the smoke before the six-minute experimental period elapsed. ${ }^{12}$ The other volunteers "stayed in the waiting room as it filled up with smoke, doggedly working on their questionnaires and waving the fumes away from their faces. ${ }^{13}$ They coughed, rubbed their eyes, and opened the window-but they did not report the smoke." 14

When asked about the smoke later on, those who had reported the smoke recalled that they thought the smoke was "strange," and while they were not sure if it was dangerous, they generally thought it was "a good idea to check it out." 15

and Teams, Organizations, and Society, 60 AnN. ReV. Psychol. 451, 452-53 (2009).

7. Ronald Adler et al., Communicating at Work: Principles and Practices for Business AND THE PROFESSIONS 235 (10th ed. 2009).

8. Bibb Latané \& John M. Darley, Group Inhibition of Bystander Intervention in Emergencies, 10 J. Personality \& Soc. PSyChOl. 215, 217 (1960).

9. Id.

10. Id. The smoke was produced by passing air through a container of titanium tetrachloride, which created a "clearly visible stream of whitish smoke." Id.

11. Id. "Soon, most subjects would get up from their chairs, walk over to the vent, and investigate it closely, sniffing the smoke, waving their hands in it, feeling its temperature, etc. The usual alone subject would hesitate again, but finally walk out of the room, look around outside, and finding somebody there, calmly report the presence of smoke." Id.

12. Id. at 218. In a another condition consisting of one participant and two confederates, only one of ten people reported the smoke; the other nine stayed in the smoky room until the six-minute experimental period ended. Id.

13. Id.

14. Id.

15. Id. at 219. Specifically, the authors describe the experimental procedure this way: After 
In contrast, those who had not reported the smoke had a variety of explanations, none of which involved anything dangerous - some thought it was steam or airconditioning vapors, some thought it was smog, and some thought it might be a "truth gas" designed to elicit honest responses to the questionnaire. ${ }^{16}$ Almost all of the subjects denied that the presence of others in the room influenced their decision not to report the smoke. ${ }^{17}$

Like the groups of students in the smoky room, jurors must work in groups, and what happens when jurors deliberate can be hard to know. Most of the information we have about what happens when juries deliberate in groups comes from post-verdict interviews with jurors and accounts published by former jurors. ${ }^{18}$ Most studies of jury communication rely on mock juries, which may or may not provide an accurate representation of the actual deliberative process. ${ }^{19}$ What we do know is that as many as thirty-three percent of jurors do not actively participate in the deliberation process, and that twenty-five percent of mock jurors do not speak at all during deliberations. ${ }^{20}$ If almost a third of jurors are not actively contributing to group deliberations, the ideal of a representative jury has not been realized. ${ }^{21}$ Furthermore, we know from studies of group processes and group deliberations that all groups - including juries - are prone to a variety of shortcomings, from loss of individual motivation in groups, ${ }^{22}$ to various cognitive biases ${ }^{23}$ to the profound influence other members of the group have on individual

six minutes, whether or not the subjects had reported the smoke, the interviewer stuck his head in the waiting room and asked the subject to come with him to the interview. After seating the subject in his office, the interviewer made some general apologies about keeping the subject waiting for so long, hoped the subject hadn't become too bored and asked if he "had experienced any difficulty while filling out the questionnaire." By this point most subjects mentioned the smoke. The interviewer expressed mild surprise and asked the subject to tell him what had happened. Thus each subject gave an account of what had gone through his mind during the smoke infusion.

16. Id.

17. Id. at 220 .

18. See, e.g., Victoria Hekkers, Exorcising A Ghost: My Experience as a Jury Foreperson, 13 Case Manager 78 (2002).

19. For an excellent summary of various jury studies, see Dennis J. Devine et al., Jury Decision Making: 45 Years of Empirical Research on Deliberating Groups, 7 PSYCHOL. PUB. POL'Y \& L. 622 (2001).

20. Donna Shestowsky \& Leonard M. Horowitz, How the Need for Cognition Scale Predicts Behavior in Mock Jury Deliberations, 28 L. HUMAN BEHAVIOR 305, 305 (2004).

21. Of course, a "representative jury pool" and a "seated jury" are not necessarily the same thing. Many citizens are called for jury service but are not selected. See, e.g., Sean Michaels, Madonna Dismissed from Jury Duty Without Hearing a Case, GUARDIAN (July 8, 2014, 2:31 PM), http://alturl.com/3bxe8, archived at http://perma.cc/D6EG-P2ER. Others actively attempt to avoid service. See, e.g., Jennifer Waters, Psst! You Want to Duck Jury Duty?, Wall St. J. (May 8, 2011, 12:01 AM), http://alturl.com/e9rhg, archived at http://perma.cc/G4B6-AERK.

22. See, e.g., Henningsen et al., supra note 1; see also infra Part III.B.

23. See, e.g., Kerr et al., supra note 3, at 713 (noting that "all other things being equal, different group processes can produce dramatically different relative biases"); see also infra notes 
jurors' cognition and behavior. ${ }^{24}$ Finally, jurors, to whom the process of group work and jury service is mostly new, are given almost no training or instruction in effective group work or decisionmaking strategies. ${ }^{25}$

So while it can be difficult to understand the inner-workings of a jury, many studies have examined group processes and group dynamics in the fields of social psychology, ${ }^{26}$ organizational psychology, ${ }^{27}$ business administration, ${ }^{28}$ and a variety of related areas. ${ }^{29}$ Studies of group performance are mixed: some studies suggest that groups generally perform better than individuals, while others do not support this finding. ${ }^{30}$ Of course, many domains, like the workplace or the military, require groups of individuals to work together and countless studies recommend the use of training to improve group performance. ${ }^{31}$ Yet very little

321-22.

24. Susan T. Fiske, Social Beings: Core Motives in Social Psychology 461 (John Wiley \& Sons eds., 1st ed. 2004); see also infra Part III.A.

25. See, e.g., 1.1 Duty of Jury Ninth Circuit Model Civil Jury Instructions (2007) (giving instruction on the law, but not on effective group work or decisionmaking strategies).

26. See, e.g., Wittenbaum \& Moreland, supra note 5, at 187 (noting that "research on small groups has a long history within social psychology").

27. See, e.g., Hackman, supra note 5 (advocating for a robust understanding of social and organizational dynamics when studying group behavior because "it makes sense to strip away the context to see how things really work only when the context is not itself a key part of how things do work - which, in group and organizational studies, it usually is"); see also Richard T. Mowday, Organizational Behavior: Linking Individuals and Groups to Organizational Contexts, 44 ANN. REV. PSYCHOL. 195 (1993).

28. See, e.g., Murphy \& McIntyre, supra note 5, at 213 (2007) (noting that "internal group dynamics within a board [have] been neglected in traditional studies linking single boards of directors characteristics to firm performance.").

29. One of the earliest definitions of the study of group dynamics described it as a "field of inquiry dedicated to advancing knowledge about the nature of groups, the laws of their development, and their interrelations with individuals, other groups, and larger institutions." DORWIN CARTWRIGHT \& ALVIN ZANDER, EDS., GROUP DYNAMICS: RESEARCH AND THEORY 7 (3d ed. 1968).

30. See Bernard A. Nijstad \& Silvia C. Kaps, Taking the Easy Way Out: Preference Diversity, Decision Strategies, and Decision Refusal in Groups, 94 J. PERSONALITY \& Soc. PSYCHOL. 860, 860 (2008) (noting that "groups have the potential to outperform individuals when it comes to the quality of decisions"); but see Kerr et al., supra note 3, at 713 (noting that "there was no simple empirical answer to this question").

31. It is worth noting that while much of the research on training has been done in the context of the workplace and job performance, these findings can and should be applied to juries. One could draw many analogies between an employee and a juror; both are paid for their time, are instructed to obtain particular results, have a "supervisor," and are expected to work with others in groups. As Aguinis and Kraiger note, "we take a point of view that training in work organizations produces clear benefits for individuals and teams, organizations, and society. We believe that training in work organizations is an area of applied psychological research that is particularly well suited for making a clear contribution to the enhancement of human well-being and performance 
of this interdisciplinary knowledge of training in effective group decisionmaking has been applied to one of the most fundamental group decisionmaking bodies - the jury. And while many empirical studies have found that jurors are competent decisionmakers, ${ }^{32}$ often reaching the same or similar decisions as judges, some additional training could be enormously helpful in assisting jurors to overcome many of the challenges all groups face in coming to decisions. We can and should use this literature to inform our understanding of the optimal functioning of the jury, to provide jurors with strategies for working in groups, and to improve jury deliberation and decisionmaking.

Specifically, jurors would benefit tremendously from additional training in group decisionmaking strategies and effective group collaboration. Jury instructions that simply tell jurors to "reach an agreement" on the evidence ${ }^{33}$ do not provide jurors with the tools and strategies they need to thoughtfully and efficiently analyze the facts and law they learn during the trial. Specific decisionmaking strategies would allow jurors to spend more time analyzing the information and law they have heard about in a trial and less time simply figuring out how to approach the information. Additionally, jurors should be trained in information sharing, which will ensure that the group discusses all relevant evidence. This can also help reduce group conformity and encourage individual jurors to mention and discuss minority views. This information sharing will help further achieve the goal of a truly diverse decisionmaking body. Finally, jurors should be trained in effective decisionmaking procedure, including the selection of the foreperson. This will help encourage more thoughtful evaluation of the evidence and help reduce the impact of status hierarchies and social conformity on group decisionmaking.

Part I of this Article discusses the development of the American jury system and specifically the development of the modern jury as a group decisionmaking body. Part II of this Article explores the concept of a "group," a term with various definitions, but a profound impact on the behavior and decisionmaking of its members. This part also explores the development and life-cycles of a group, including status hierarchies, group cohesion, group norms, and roles. Part III discusses the profound influence groups have over their members, including the individual tendency to conform to the group, as well as various motivation losses that occur within a group, like social loafing and free-riding. Part IV recommends more intensive training in decisionmaking, information-sharing, and jury procedure as a way to improve group decisionmaking and encourage jurors to make more careful and accurate evaluations of the law and evidence before reaching a verdict.

in organizational and work settings as well as in society in general." Aguinis \& Kraiger, supra note 6 , at 452-53.

32. See Jennifer K. Robbennolt, Evaluating Juries by Comparison to Judges: A Benchmark for Judging?, 32 FLA. ST. U. L. REV. 470, 470 (2005).

33. 3.1 Duty to Deliberate, Ninth Circuit Model Civil Jury Instructions (2007). 


\section{A Jury of PeErs: From Trial by Ordeal to Group Decisionmaking}

As a society, we must have a way to handle crimes, disagreements, and disputes, and while the jury system has a long history dating back to the Magna Carta, ${ }^{34}$ it is in fact predated by many other dispute resolution processes. During the Middle Ages, disputes were settled by methods like trial by wager of battle, in which "the two disputing parties engaged in a formal duel under the assumption that God would determine which party was in the right and should prevail,", ${ }^{35}$ and trial by ordeal, in which people were submerged in cold water (those who sunk to the bottom were innocent, while those who rose to the top were guilty) or burned with hot irons ("festering after three days was a sign of guilt"). ${ }^{36}$ In 1215, Catholic priests, who had played a large part in these various trial procedures, were forbidden from participating, and these and similar procedures came to an end. ${ }^{37}$ In their place, we began to see the slow and uneven development of decisions by groups of jurors throughout the British Empire and in all of the American colonies. ${ }^{38}$

Early American jury trials similarly bore little resemblance to the process we see today. ${ }^{39}$ English Puritans in the colonies instructed jurors to "Feare God and Keepe his Commandments," and individual colonies created jury systems based in part on their individual cultural and religious beliefs. ${ }^{40}$ Moreover, these early juries were composed entirely of men, and jury service was typically limited to landowners. ${ }^{41}$ But as the country continued to change, the jury system also

34. The Magna Carta required that charges against barons should be heard by other barons, their "peers," rather than by the king. VIDMAR \& HANS, supra note 2, at 66.

35. Id. at 22; see also GeOrge R.R. MARTIN, A GAME OF Thrones 421 (1996) (Tyrion Lannister noted, "The gods know the truth of my innocence. I will have their verdict, not the judgment of men. I demand trial by combat."). Tyrion found himself in this unenviable position more than once: "I am innocent, but I will get no justice here. You leave me no choice but to appeal to the gods. I demand trial by battle.” GeOrge R.R. MArtin, A STORM OF SwOrds 963 (2000).

36. VIDMAR \& HANS, supra note 2, at 22.

37. Id. at 23. As Vidmar \& Hans note, even at the time of its use, the inadequacies of trial by ordeal "as a method of proof were apparent to many members of the Church." Id.

38. Id. at 24, 36 (noting that the 1606 charter to the Virginia Company provided for jury trial, and by 1624 juries were available for all civil and criminal cases. In 1623, the right to a jury trial was recognized in New Plymouth. The Massachusetts Bay Colony introduced jury trials in 1628 . The Colony of West New Jersey formally recognized them in 1677, as did Pennsylvania in 1682. In fact, juries were probably in use before their formal recognition. Rhode Island had jury trials even before the establishment of the colony's government and set of laws in 1647.).

39. Id. at 47. "The seeds of the jury system may have been in existence in the form of proof by witnesses before William the Conqueror defeated King Harold's army in 1066, but the Norman conquest of England set the stage for a more formal use of sworn testimony." Id. at 23.

40. Id. at 48 .

41. James C. Oldham, Trial by Jury: The SEVEnth Amendment AND ANGLO-American SPECIAL JURIES 176 (2006). 
evolved. In the second half of the nineteenth century, defendants were given the right to testify, lawyers began to have a bigger role in the process, and court systems began to take form, with separate courts of appeals. ${ }^{42}$ At the same time, trials were almost always short and not overly concerned with procedure. ${ }^{43}$ Trials often took less than half an hour, and juries sometimes heard as many as six cases in a day. ${ }^{44}$ Nevertheless, the jury of peers - composed of groups of people from an accused's community - began to take shape and the group decisionmaking body became seen as a democratic ideal, one that promoted accurate fact-finding and provided a check on the powers of the government. ${ }^{45}$

While rates of jury trials have declined in both criminal and civil cases in the United States, the jury still plays an important role in the American justice system. ${ }^{46}$ And despite all of this change, one thing about the American jury system that has remained relatively constant since its inception is the ideal of a representative jury with dual goals - a jury of peers that is composed of a "reasonable cross-section" of the community. ${ }^{47}$ The jury of peers is intended to give defendants a fair trial by including in the jury a representative number of people who share his "cultural, linguistic, ethnic, or, possibly, socioeconomic circumstances." ${ }^{\prime 48}$ Conversely, the reasonable cross-section requirement ensures that members of the jury are drawn from all segments of the community in which the trial occurs. ${ }^{49}$ As the United States Supreme Court has noted, "[p]roviding an accused with the right to be tried by a jury of his peers gave him an inestimable safeguard against the corrupt or overzealous prosecutor and against the compliant, biased, or eccentric judge., ${ }^{50}$

42. For an excellent summary of the development of the modern jury system in the United States, see VIDMAR \& HANS, supra note 2, at 41-64.

43. Id. at 59 .

44. Id. at 60.

45. RANDOlPh N. JonAKit, THE AMERICAN JURY SySTEM 36 (2003).

46. VIDMAR \& HANS, supra note 2, at 60-61. This decline can be attributed to a number of factors, from the increasing use of dispute resolution, which has moved disputes from courts and juries to mediators and negotiators, to plea bargaining, once unusual in the criminal system, which reduces the number of criminal cases that go to trial. $I d$. at 63 .

47. Thiel v. S. Pac. Co., 328 U.S. 217, 220 (1946).

48. OLDHAM, supra note 41, at 176-77.

49. Thiel, 328 U.S. at 220.

50. Duncan v. Louisiana, 391 U.S. 145, 156 (1968). The term "American jury system" includes many discrete systems. Each state, the federal government, and the District of Columbia has its own courts, laws, and practices, with multiple jury systems. Moreover, jury systems differ in criminal cases and civil matters. All of these systems do share some important characteristics. The Sixth Amendment to the Constitution provides that "[i]n all criminal prosecutions, the accused shall enjoy the right to a speedy and public trial, by an impartial jury of the State and district wherein the crime shall have been committed[.]" U.S. ConST. amend. VI. The United States Supreme Court has limited this right by holding that the Sixth Amendment does not guarantee jury trials for "petty" offenses, or those carrying a potential punishment of less than six months' imprisonment. See Baldwin v. New York, 399 U.S. 66, 68 (1970). Since 1968, this constitutional 
Of course, the representative jury is based on the premise that while individual jurors may view the evidence through the lens of their past experiences ${ }^{51}$ they must agree as a group on the legal implications of the evidence they have heard in order to reach a verdict. They must reconcile their individual perspectives and arrive at a group decision. ${ }^{52}$ The process by which jurors reach a group decision and the characteristics of the deliberation process began receiving attention in the legal literature starting in 1950 with the Chicago Jury Project. ${ }^{53}$ Since then, hundreds of studies have further explored juries and jury decisionmaking in mock jury experiments, as well as in interviews with real jurors. ${ }^{54}$ And there have been significant improvements in the process by which

right to a jury trial has applied to both state and federal criminal trials. Duncan, 391 U.S. at 155-56. In civil cases in federal court, the right to a jury trial is governed by the Seventh Amendment, which provides that "[i]n Suits at Common Law, where the value in controversy shall exceed twenty dollars, the right of trial by jury shall be preserved." U.S. CONST. amend. VII. This constitutional right to a jury trial in civil cases only applies to federal cases, but most states do afford jury trials in civil matters for cases above the level of the small claims court. See AMERICAN JUDICATURE SOCIETY, RIGHT TO JURY TRIAL(2013), available at http://alturl.com/vmmgu, archived at http://perma.cc/7863-LEFP.

51. The story model is the most prevalent theory on how individual jurors view and interpret the facts they see in a trial. In this model, jurors use instructions to derive lists of the features of individual crimes or claims; if the story they have constructed shares enough features with the instructions, they will find the defendant guilty, and if it is missing too many requirements, they will find the defendant innocent. REID HASTIE ET AL., InSIDE THE JURY 22-23 (1983); see also Peter W. English \& Bruce D. Sales, A Ceiling or Consistency Effect for the Comprehension of Jury Instructions, 3 PSYCHOL. PUB. POL'Y \& L. 381, 382 (1997).

52. In federal courts, juries must consist of at least six and no more than twelve members in civil trials, and are normally composed of twelve jurors in criminal trials. FED. R. CIV. P. 48(a); FED. R. CIV. P. 23(b). In civil cases in state court, size and unanimity requirements vary considerably. See Thomas Cohen \& Ron Malega, Bureau of Justice Statistic's Survey of StATE COURT ORganizations (2011), available at http://alturl.com/cxfxi, archived at http://perma.cc/H5LL-CCQ6. About half of states allow non-unanimous verdicts in civil cases, and fewer than half require twelve-person juries. Id. For a recent report on size and unanimity requirements in all jurisdictions. Id. In both civil and criminal cases in federal courts, the jury must reach a unanimous verdict. FED. R. CRIM. P. 31(a); FED. R. CIV. P. 48(b). In 1972, the United States Supreme Court held that the Sixth Amendment requires a unanimous verdict in criminal cases, but that this Sixth Amendment guarantee does not apply to state criminal courts by virtue of the Due Process Clause of the Fourteenth Amendment. Apodaca v. Oregon, 406 U.S. 404, 406 (1972). Today in state courts, only Louisiana and Oregon allow non-unanimous jury verdicts in criminal cases and the United States Supreme Court recently denied certiorari in Jackson v. Louisiana, a case that challenged the constitutionality of Louisiana's law. Jackson v. Louisiana, 134 S. Ct. 1950 (2014).

53. For an excellent review of the University of Chicago Jury Project, see Valerie P. Hans \& Neil Vidmar, The American Jury at Twenty-Five Years, 16 LAW \& SoC. INQUIRY 323, 324-26 (1991).

54. See Devine et al., supra note 19, at 622. 
jurors are asked to make decisions: many courts have begun to pre-instruct jurors on the applicable law before the introduction of evidence, and some courts allow the jury to take notes, to submit questions to witnesses, and to consult written copies of jury instructions during deliberations. ${ }^{55}$

At the same time, there has been extensive research on group decisionmaking in the social sciences. ${ }^{56}$ Much of this research supports the idea that groups can be effective decisionmakers, often reaching equivalent or better decisions than individuals could have on their own. ${ }^{57}$ Some research suggests that representative juries composed of people with different backgrounds and experiences promote accurate fact-finding because such a group is likely to hold diverse perspectives on the evidence, engage in more thorough debate, and more closely evaluate the facts. ${ }^{58}$ On the other hand, there are also a variety of problems associated with group decisionmaking, from loss of motivation in groups due to social loafing and the free-rider effect, to the vulnerability of groups, to various cognitive biases and errors. ${ }^{59}$ Group dynamics also play a role; it can be difficult for an individual to stand up to the group when her opinion is in the minority. ${ }^{60}$ But despite this extensive literature, almost none of the insights gained from studies of group dynamics and training in group decisionmaking has been applied to juries to improve the process by which this important group deliberates and makes decisions.

While judges and lawyers instruct jurors to decide only the facts, this instruction assumes a clear division between the law and the facts, or that all individual jurors will view the facts as they are. ${ }^{61}$ But in fact, application of law to facts involves certain value judgments and "the deliberation provides an excellent opportunity for the jury members to influence one another on the

55. See Hon. Gregory E. Mize (Ret.) et al., The State-Of-The-States Survey Of Jury IMPROVEMENT EFFORTS: ACOMPENDIUMREPORT 36 (2007), available at http://alturl.com/egwby, archived at $\mathrm{http}: / /$ perma.cc/ A9HF-WZRB.

56. For a recent review of studies related to group decisionmaking, see Norbert L. Kerr \& Scott Tindale, Group Performance And Decisionmaking, 55 ANN. REV. PsYCHOL. 623 (2004).

57. Nijstad \& Kaps, supra note 30, at 860; see also Gregory S. Berns et al., Neurobiological Correlates of Social Conformity and Independence During Mental Rotation, 58 BIOLOGICAL PSYCHIATRY 245, 245 (2005). For a discussion of the advantages of group decisionmaking in corporate governance, see Stephen M. Bainbridge, Why A Board? Group Decisionmaking in Corporate Governance, 55 VAND. L. REV. 1 (2002).

58. VIDMAR \& HANS, supra note 2, at 74. As Vidmar and Hans note, the "idea of a representative jury is a compelling one. A jury of people with a wide range of backgrounds, life experiences, and world knowledge will promote accurate fact-finding." Id.

59. Tatsuya Kameda et al., Democracy Under Uncertainty: The Wisdom of Crowds and the Free-Rider Problem in Group Decision Making, 118 PsYCHOL. REV. 76, 76-77 (2011).

60. Robert B. Cialdini \& Noah J. Goldstein, Social Influence: Compliance and Conformity, 55 ANN. REV. PSYCHOL. 591, 612 (2004) (noting that "the extent to which one identifies with a message source - be it a majority or a minority - is a significant factor in determining the information processing strategies one employs as well as the outcome of an influence attempt").

61. VIDMAR \& HANS, supra note 2, at 144. 
meaning of facts and the value judgments implicit within them." 62 And as a group of individuals attempting to reach a collective decision, juries-like all other human groups - are subject to common drawbacks of group decisionmaking. So while the representative jury is an improvement from the time of trial by combat, studies of group dynamics and training in group decisionmaking can inform that process and we should draw from the conclusions of those studies to give individual jurors more guidance about how to avoid the vulnerabilities associated with group decisionmaking and reach better decisions.

\section{We Are A Sort of They: How to Define A “Group"}

"Father, Mother, and Me, Sister and Auntie say

All the people like us are We, and every one else is They.

And They live over the sea, While We live over the way,

But-would you believe it? - they look upon We

As only a sort of They!"

-Rudyard Kipling ${ }^{63}$

When fish swim together they are a "school." When lions hunt collectively, it is a "pride." When chimpanzees cooperate to defend fruit trees, they are a "troop." And when two or more human beings "are connected by and within social relationships," they are a "group." ${ }^{64}$ To understand how groups make decisions and how we can train them to make better decisions, we first need to understand what groups are and how they evolve, but the term "group" can be difficult to define. ${ }^{65}$ For some, the critical factor in defining a group is the experience of a common fate. ${ }^{66}$ For others, group members must have some perception of themselves as members of the same social category. ${ }^{67}$ What these varying descriptions all have in common is a collection of individuals who "perceive themselves in terms of their group membership." 68

62. $I d$.

63. RudyARD KIPLING, WE AND THEY (1926).

64. DONELSON R. Forsyth, GROUP DYNAMics 3 (5th ed. 2010).

65. Id. (observing that theorists are not of one mind when it comes to defining the word group.)

66. See, e.g., Chester A. Insko et al., Interindividual-Intergroup Discontinuity in the Prisoner's Dilemma Game: How Common Fate, Proximity, and Similarity Affect Intergroup Competition, 120 OrG. BEHAV. \& HuM. DeCISION PROCESSES 163, 169 (2013) (some examples of groups with a "common fate" include "a migrating flock of birds, a moving herd of buffalo, parading soldiers, [and] a marching band ....”).

67. Colin Wayne Leach, Group-Level Self-Definition and Self-Investment: A Hierarchical (Multicomponent) Model of In-Group Identification, 95 J.PERSONALITY \& SOC. PSYCHOL. 144, 146 (2008) (noting that "in-group identification is indicated by a 'depersonalized' self-perception, whereby individuals come to 'self-stereotype' themselves as similar to other members of their ingroup").

68. Id. (emphasis in original). 
We can think of "groupness" as fitting along a continuum; whether a collection of people becomes a group depends on whether they possess entitativity, the perception of being a coherent whole or an entity. ${ }^{69}$ Whether and to what extent individuals become a group depends on their similarity, common fate, proximity, and ongoing interaction. ${ }^{70}$ For example, people standing in line together are proximate to one another, but do not possess any other characteristics of a group and probably do not consider themselves a group. Conversely, a group of people brought together to serve on a jury are similar to the extent they are all jurors, share the common fate of reaching a verdict, are proximate to one another in the courtroom and during deliberations, and have ongoing interaction for the duration of the trial. All of these factors encourage cohesion and social integration, which in turn gives the individual jurors a sense of group membership. ${ }^{71}$

Like other groups of people, jurors are motivated to belong to social groups; they want to have strong and stable relationships with other people and form these bonds easily. ${ }^{72}$ In a famous study testing this idea, researchers at a summer camp in Robbers Cove, Oklahoma divided young campers into two groups. ${ }^{73}$ The boys were previously unacquainted, but after a week of living with their assigned group - the Rattlers or the Eagles - the groups formed intense team loyalties. ${ }^{74}$ Membership in social groups can also have profound impacts on an individual's well being - both psychological and physical. ${ }^{75}$ For example, in a study of stroke sufferers, the ability to maintain existing group memberships was as important to

69. Namkje Koudenburg et al., Conversational Flow and Entitativity: The Role of Status, 53 BRIT. J. SOC. PSYCHOL. 350, 351 (2014) (noting that "[ $\mathrm{t}$ ] he concept of entitativity is an important determinant of processes within and between groups").

70. FISKE, supra note 24 , at 461.

71. Id. Of course, "groupness" also depends on context. For example, people who live in the United States would identify themselves as "Americans" when compared to a group of people who live in a different country, but in many other contexts would not see themselves as similar to others in that "group." Moreover, all of those people would further self-identify as a member of many different ethnic, social, and cultural groups.

72. Id.; see also Donald F. Sacco et al., Reactions to Social Inclusion and Ostracism as a Function of Perceived In-Group Similarity, 18 GROUP DYNAMICS: THEORY, RES., \& PRAC. 129, 130 (2014) (observing that "unfulfilled belongingness needs have a decidedly negative impact on well-being"').

73. MuZAFER SHERIF ET AL., THE RoBbers CAVE EXPERIMENT, INTERGROUP CONFLICT AND COOPERATION 94-95 (1988).

74. Id.

75. S. Alexander Haslam et al., Social Identity, Health and Well-Being: An Emerging Agenda for Applied Psychology, 58 APPLIED PsYCHOL. 1, 2-3 (2009) (explaining that "[g]roups are not simply external features of the world that provide a setting for our behaviour. Instead they shape our psychology through their capacity to be internalised and contribute to our sense of self. Thus, far from being 'just another' factor that impinges upon the health of individuals, social identities - and the notions of 'us-ness' that they both embody and help create - are central to health and well-being."). 
recovery as the ability to overcome cognitive difficulties with memory and language. ${ }^{76}$ Similarly, a study of nursing home residents found that a strong sense of identity associated with perceived membership in social groups was a much better predictor of the residents' well-being than their level of dementia. ${ }^{77}$

Once people are part of a group, they are powerfully influenced by other group members. In the smoke study, for example, the lack of reaction from others in the room influenced the participants to believe that the smoke was not serious and they therefore did not need to report it. ${ }^{78}$ As the researchers noted, individuals were "likely to look at the reactions of people around [themselves] and be powerfully influenced by them." 79 Other researchers put forth different theories to explain this "bystander effect." ${ }^{" 10}$ For example, studies of diffusion of responsibility suggest that as the number of people in a group increases, each individual member will be less responsible for helping because others will take responsibility. ${ }^{81}$ Both of these theories focus on the situation and how the presence of others in a situation motivates individual behavior.

Furthermore, belonging to a group has such a strong impact on individual cognition and behavior that even people who only imagine being in a group have concepts of unaccountability triggered. These feelings of unaccountability can cause group members to decide the situation does not call for their individual assistance. ${ }^{82}$ This sense of unaccountability occurs because "part of the concept of being in a group is the notion of being lost in a crowd, being deindividuated, and having a lowered sense of personal accountability." ${ }^{\text {"3 }}$ For example, people who were asked to imagine that they won a dinner for themselves and thirty friends subsequently pledged less to charity than those who imagined winning a dinner for a group of ten people, while those who imagined a dinner with only one friend pledged more than either of the larger groups. ${ }^{84}$ Similarly, when people were asked to imagine being with a friend in a crowded movie theater, or to imagine being with a friend in an empty movie theater, those who imagined a crowded theater pledged significantly less to an annual giving campaign (on

76. Catherine Haslam et al., Maintaining Group Memberships: Social Identity Continuity Predicts Well-Being After Stroke, 18 NeuropsyChOL. REHABILITATION 671, 684 (2008).

77. Catherine Haslam et al., The Social Treatment: The Benefits of Group Interventions in Residential Care Settings, 25 Psychol. \& AGING 157, 163 (2010).

78. Latané \& Darley, supra note 8 , at 220.

79. Id.

80. Id.

81. Id. at 215 (noting "[i]f an individual is alone when he notices an emergency, he is solely responsible for coping with it. If he believes others are also present, he may feel that his own responsibility for taking action is lessened, making him less likely to help").

82. Stephen M. Garcia et al., Crowded Minds: The Implicit Bystander Effect, $83 \mathrm{~J}$. PERSONALITY \& SOC. PSYCHOL. 843, 851 (2002).

83. Id. at 845 .

84. Id. at 846 . Subjects who imagined groups of thirty pledged an average of $3.6 \%$ of their after-tax earnings, subjects who imagined groups of ten pledged an average of $3.9 \%$, and subjects who imagined dinner with one friend pledged an average of $4.2 \%$. Id. 
average between $\$ 100$ and $\$ 249$ ) than those who imagined being in an empty theater (on average between $\$ 500$ and $\$ 999$ ). ${ }^{85}$ It seems that simply imagining the presence of others influences behavior and can lead to lessened levels of responsibility. ${ }^{86}$

Being a member of a group can therefore have a profound impact on an individual's cognition and behavior. But the process of becoming a group takes place in stages. Just as individuals grow and develop through predictable stages, so do groups of jurors. As one author noted, "[g]roups are not static; nor do they emerge, like the mythical Athena, fully formed in an act of divine creation." Throughout the life cycle of the group, individual jurors must establish and maintain relationships with other members of the jury. ${ }^{88}$ Various changes occur within the jury from the time it is empanelled to the time it reaches a verdict, including the evolution of status hierarchies, group cohesion, group norms, and group roles. We can examine these stages to get a better sense of how group membership influences individual jurors' decisionmaking and the decisionmaking of the jury as a whole.

\section{A. Status}

Many species, from humans to birds, fish, and insects quickly form status hierarchies when placed in a group setting. ${ }^{89}$ In humans, the status level of various group members can be seen in both non-verbal and verbal behavior.

85. Id. at 846-47. Specifically, subjects in the "crowded theatre" condition were told: "Imagine that you and a friend are sitting in a crowded movie theater. There are people in front of you, behind you, and to your sides. Although there are some children, the audience is mostly adults, and you are just watching the movie previews." Those in the "empty theatre condition" were told: "Imagine that you and a friend are sitting alone in a movie theater. You and your friend have the entire theater to yourself, and you are just watching the movie previews." Id. at 846 (internal quotations omitted).

86. Id. at 848. In the same study, subjects who were asked to think about a crowded movie theatre and then asked to respond to real words or nonsense words on a computer screen responded more quickly to real words regarding unaccountability (unaccountable, innocent, and exempt) than they did to other neutral words (whimsical and impenetrable); in other words, because they were thinking about being in a large group of people, they were more responsive to words related to the unaccountability that occurs in groups. Specifically, those in the "crowded theatre" condition responded to words regarding unaccountability in an average of 517 milliseconds, while those in the "empty theatre" condition responded to the same words took an average of 587 milliseconds to respond. Id. at 849.

87. Erik K. Stern, Probing the Plausibility of Newgroup Syndrome: Kennedy and the Bay of Pigs, in Beyond Groupthink: Political Group Dynamics and Foreign Policy-Making at 155 (Paul 't Hart et al. eds., 1997).

88. John M. Levine \& Richard L. Moreland, Progress In Small Group Research, 41 ANN. REV. PSYCHOL. 585, 598 (1990).

89. Cameron Anderson \& Gavin J. Kilduff, The Pursuit of Status in Social Groups, 18 CURRENT Directions PsYCHOL. SCI. 295, 295 (2009). 
High-status members tend to make more eye contact with other members of the group, speak more firmly and with fewer hesitations, and have better posture. ${ }^{90}$ Similarly, high-status members speak and are spoken to more often, and are more likely to criticize and interrupt other members of the group. ${ }^{91}$ Moreover, in groups, the status of the speaker can be more important than the content of her contribution. One study of navy bombing crews found that when the captain suggested an answer to a navigation problem, other members of the crew were more likely to accept the answer than they were when it came from the navigator, even though the navigator was more likely to have the correct answer. ${ }^{92}$

Status within juries similarly forms very quickly after the group is composed, often before group members engage in any real interaction with one another. ${ }^{93}$ One explanation for this immediate status hierarchy is that group members have certain expectations about each other and how much they are likely to contribute to the group. ${ }^{94}$ When the jury forms, its members will evaluate each other and decide how much value they think individual members can provide to the group; those perceived as being the most vital will be given the highest status. ${ }^{95}$ These expectations can be based on immutable characteristics like race, age, or gender, as well as on information group members reveal about themselves, like occupation or prior jury experience. ${ }^{96}$ The jury accords higher status to people with characteristics others expect will be helpful in reaching a verdict. ${ }^{97}$

Like individuals in any group, jurors also participate in group discussion at markedly different rates and high status members tend to dominate the discussion. ${ }^{98}$ In one study, three of twelve jurors were responsible for more than

90. Levine \& Moreland, supra note 88, at 598.

91. Id.

92. Charlan Jeanne Nemeth, Dissent as Driving Cognition, Attitudes, and Judgment, 13 SoC. COGNITION 273, 275 (1995).

93. Levine \& Moreland, supra note 88, at 598-99.

94. Id. at 599; see also Brent Simpson et al., Status Hierarchies and the Organization of Collective, 30 SOC. THEORY 149, 152 (2012) (noting that "those group members for whom performance expectations are higher are granted more opportunities to perform, generate more performance outputs, and have their performance outputs more positively evaluated").

95. Gavin J. Kilduff \& Adam D. Galinsky, From the Ephemeral to the Enduring: How Approach-Oriented Mindsets Lead to Greater Status, 105 J. PERSONALITY \& SOC. PSYCHOL. 816, 817 (2013) (noting that it is "perceptions of value, rather than value itself, determine status. As a result, groups do not necessarily always place their most valuable or competent members in charge; rather, the ones that appear to be the most valuable or competent achieve higher rank.").

96. Levine \& Moreland, supra note 88, at 599.

97. While this status can change over time as group members contribute to the discussion or reveal more about themselves, it can be difficult for group members with low-status to overcome this perception. Id. Another theory of rapid status development posits that group members quickly assess one another's strength and dominance upon meeting, engage in dominance "contests" like maintaining eye-contact until one person looks away, and assign status based on the results of these contests. Id.; see also Anderson \& Kilduff, supra note 89, at 297.

98. HASTIE ET AL., supra note 51, at 28. 
half of the discussion, while another study found that in six-member juries, five percent of the jurors did not speak at all, and in twelve-member juries, twenty percent of mock jurors did not speak. ${ }^{99}$ Male jurors tend to speak more than female jurors, and jurors with higher economic status also speak more often. ${ }^{100}$ Physical location at the jury table is also important: jurors at the ends and middle of the table participate more than those in the corners. ${ }^{101}$

Generally speaking, higher-status jurors will be more influential during group deliberations and decisionmaking. ${ }^{102}$ Because jurors with higher status have more opportunities to speak, they similarly have more opportunities to guide the course of deliberation, and to ultimately influence the verdict. ${ }^{103}$ All of these things contribute to some jurors guiding the verdict and having greater control over the jury's final decision. ${ }^{104}$ This result - that an individual juror with high status can exert tremendous influence over the outcome of a trial — is at odds with the ideal of a representative jury system. Studies in group decisionmaking and group dynamics, however, suggest that jurors can be given training and techniques to ensure that individual jurors, even those with lower status in the group, have sufficient opportunities to voice their opinions and contribute to the deliberative process. ${ }^{105}$

\section{B. Cohesion}

On April 17, 1961, less than three months into his presidency, President John F. Kennedy ordered the Bay of Pigs invasion in an attempt to overthrow the Fidel Castro regime in Cuba. ${ }^{106}$ Because it was only the beginning of the Kennedy administration, most of the decisionmakers and advisors to the President had been in their positions for only a few months and most lacked close personal relationships with the President. ${ }^{107}$ Secretary of State Dean Rusk just met Kennedy for the first time in December 1960, and National Security Assistant McGeorge Bundy knew Kennedy only socially. ${ }^{108}$ Bundy later said that if he had known Kennedy better and enjoyed more rapport with him, he would have

99. Id. (citing various studies).

100. Id. (citing various studies).

101. Id. (citing various studies).

102. Stern, supra note 87 , at 157.

103. Levine \& Moreland, supra note 88, at 600 (“'A] person's status often affects his or her relations with other group members. People with higher status have more opportunities to exert social influence, try to influence other group members more often, and are indeed more influential than people with lower status.").

104. Id. As the authors note, "[a] person's status can also affect how he or she is evaluated by others. Even when they behave in similar ways, people with higher status are often evaluated more positively than people with lower status." Id.

105. See infra Part IV.B.

106. Stern, supra note 87 , at $178-79$.

107. Id. at 178 .

108. Id. at 179 . 
questioned the President's support of the failed invasion. ${ }^{109}$

Kennedy's advisers on the Bay of Pigs invasion were considered the "best and brightest," and included "[e]lder statesmen, cunning bureaucrats, captains of industry, and academic luminaries" all of whom participated in extensive group deliberations with the President. ${ }^{110}$ But the failed invasion was a foreign policy disaster. Kennedy himself later asked, "[H]ow could I have been so stupid as to let them go ahead?"111 How did so many smart individuals make such a poor group decision? In his book, A Thousand Days, Arthur Schlesinger writes that Kennedy "could not know which of his advisers were competent and which were not. For their part, they did not know him or each other well enough to raise hard questions with force and candor."112 Because they were a new group, and therefore unfamiliar with each other, group members lacked "idiosyncrasy credit" and were more susceptible to conformity - they did not know Kennedy so they did not speak up. ${ }^{113}$

Part of the problem was that the group — Kennedy's administration — was new and its members were not yet cohesive. A group is cohesive when its members "identify strongly with its key features and aspirations." 114 One of the earliest definitions of group cohesiveness is "all the forces acting on the members to remain in the group." 115 Unlike status hierarchies, cohesion does not occur immediately when a group is formed, but instead develops during the life cycle of the group when it has had the chance to work together and its members have gotten to know one another. ${ }^{116}$

Many studies find that high group cohesion leads to increased productivity and better group performance. ${ }^{117}$ Specifically, group cohesion can enhance group

109. Id.

110. Id. at 153.

111. Stern, supra note 87 , at 153 .

112. Arthur M. Schlesinger, JR., A Thousand Days: John F. Kennedy in the White House 258 (2002).

113. Stern, supra note 87 , at 179.

114. Rupert Brown, Group Processes: Dynamics Within and Between Groups 46 (2000); see also Michael A. Hogg, The Social Psychology of Group CoHesiveness: From ATTRACTION TOSOCIAL IDENTITY 1 (1992) (defining cohesiveness as "the descriptive and technical term used by social psychologists to refer to the essential property of social groups that is captured in common parlance by a wide range of other expressions, such as solidarity, cohesion, comradeship, team spirit, group atmosphere, unity, 'oneness.' 'we-ness,' 'groupness,' and belongingness").

115. Leon Festinger, Informal Social Communication, PSYCHOL. REV. 271, 274 (1950).

116. Daniel J. Beal et al., Cohesion and Performance in Groups: A Meta-Analytic Clarification of Construct Relations, 88 J. APPLIED PSYCHOL. 989, 995 (2003).

117. Charles R. Evans \& Kenneth L. Dion, Group Cohesion and Performance: A MetaAnalysis, 43 Small Group RES. 690, 695 (2012) (finding that cohesive groups were more productive than non-cohesive groups in a meta-analysis of twenty seven studies concerning group cohesion and productivity). As the authors noted, however, this meta-analysis consisted primarily of groups like sports teams and military units, where productivity could be measured in terms of 
productivity, improve morale, facilitate group communication, and reduce group hostility. ${ }^{118}$ Furthermore, social loafing, a phenomenon where group members reduce their own efforts because they assume that other members of the group will put forth the necessary effort, ${ }^{119}$ can be reduced in highly cohesive groups. ${ }^{120}$ If a jury is cohesive, it is also more likely to reach consensus on a verdict. ${ }^{121}$ Moreover, if jurors are simply told they are likely to be able to work well together, cohesion is increased and group performance improves. ${ }^{122}$ Finally, by taking part in training about effective decisionmaking strategies together, cohesion can be increased and group performance improved. ${ }^{123}$

\section{Norms}

Although groups bring many benefits to decisionmaking, including diversity of backgrounds, perspectives, and experiences, the benefits of group decisions can be significantly influenced by an individual member's willingness to stand up to the majority or to act in a way that conflicts with the norms of the group. As members of a social group, jurors will tailor their behavior to be consistent with the norms of the group situation, and can feel "anxious, tense, and embarrassed" if they fail to conform to those norms. ${ }^{124}$ Social norms tell us what

objective performance criteria. In other groups, like juries, "performance may depend on more than the product; it may also depend on the process of production." Id. at 696.

118. Michael A. Hogg \& Dominic Abrahms, Social identifications: A Social PSYCHOLOGY OF INTERGROUP RELATIONS AND GROUP PROCESSES 94 (1990) (citing various studies that have found group cohesion "enhances group productivity and performance, increases conformity to group norms, improves morale and job satisfaction, facilitates intragroup communication, reduces intragroup hostility ... . and increases feelings of security and selfworth"). Other studies reach different findings. See, e.g., BROWN, supra note 114, at 217 ("[T]he relative unimportance of cohesiveness [has] been confirmed in field studies of naturally functioning groups."). Finally, some sources suggest the relationship between cohesion and productivity is more reciprocal: while "cohesion aids performance," it is also true that performance causes changes in cohesiveness. FORSYTH, supra note 64, at 138.

119. See infra Part III.B.

120. Steven J. Karau \& Kipling D. Williams, The Effects of Group Cohesiveness on Social Loafing \& Social Compensation, 1 GROUP DYNAMICS: THEORY, RES., \& PRAC. 156, 165 (1997).

121. JeFFrey T. Frederick, MASTERING Voir Dire AND Jury SELECTION: GAIN AN EdGE In QUESTIONING AND SELECTING A JURY 268 (3d ed. 2012).

122. Id.

123. See infra Part IV.

124. Stanley Milgram \& John Sabini, On Maintaining Social Norms: A Field Experiment in the Subway, in SMALl Groups \& SOCIAL INTERACTION 190 (Blumberg et al. eds., 1983). One of Milgrim's most famous studies involved subways in New York City. Milgrim asked graduate students to do that thing "that just isn't done" on the subway in a major city: approach a rider and ask her to give up her seat. Id. at 192. As Milgrim notes,

The requirements of appropriate social behavior on the subway are, on the face of it, simple. People get on the subway for a very clear and specific reason: to get from one 
is appropriate and acceptable behavior in a given situation, and can have a significant impact on cognition and behavior. ${ }^{125}$

There are two main types of social norms - descriptive and injunctive - and both have a powerful influence on how individuals choose to act in social situations. ${ }^{126}$ Descriptive norms are our beliefs about what others are doing, while injunctive norms are our feelings about what constitutes acceptable behavior in others. ${ }^{127}$ For example, people in high-energy-consuming households reduced their level of energy consumption when they were told that their electricity consumption was higher than their neighbors (they had violated a descriptive norm), and they reduced it even more when they were told that excessive use of electricity is undesirable (they had violated an injunctive norm). ${ }^{128}$ Similarly, college students who believe it is not socially acceptable for teenagers to drink are significantly less likely to use alcohol, ${ }^{129}$ and those who believe it socially

place to another in a brief period of time. The amount of interaction among the riders required for this purpose is minimal and the rules governing this interaction are widely adhered to. One rule of subway behavior is that seats are filled on a first-come, firstserved basis. Another implicit rule is one that discourages passengers from talking to one another. The experimenters in this study violated these rules by asking people for their seats.

Id. at 186. When riders were given no explanation ("Excuse me. May I have your seat?") they got up or slid over $68.3 \%$ of the time, and when they were given a trivial reason ("Excuse me. May I have your seat? I can't read my book standing up.") they gave up their seat $41.9 \%$ of the time. Id. But several of the other passengers who overheard the exchange openly chided the person who had given up the seat, saying things like, "Did you see that? He asked for a seat!" Id. Other passengers openly stared at the student subjects who asked for a seat. Id. at 187-89. Finally, many of the student subjects found it very difficult to carry out the experiment; they were anxious, tense, embarrassed, and were frequently "unable to vocalize the request for a seat and had to withdraw." Id. As Milgrim notes, "[a]n important aspect of the maintenance of social norms is revealed in [this] emotional reaction" on the part of the student subjects. Id. at 190. The students were so uncomfortable violating the social norm of the subway and doing the thing that "just isn't done" that they sometimes could not do it at all. Id.

125. Cialdini \& Goldstein, supra note 60 , at 597 (noting that "a close examination of the seemingly inconsistent literature on norms and their impact on behavior yields a meaningful distinction between norms that inform us about what is typically approved/disapproved (injunctive norms) and those that inform us about what is typically done (descriptive norms)").

126. P. Wesley Schultz et al., The Constructive, Destructive, and Reconstructive Power of Social Norms, 18 PSYCHOL. SCI. 429, 430 (2007).

127. Id.

128. Id. at 431-32. Specifically, "if the household had consumed more than the average, the researcher drew a sad face (L). Id. The valence of the emoticon was used to communicate an injunctive message of approval or disapproval for the amount of energy being consumed." Id. at 431. Furthermore, the authors noted that they believed these findings will apply to many other behaviors, including seat-belt use, littering, consumer choices, and illegal downloading of music. Id. at 433 .

129. Andrew Hallim et al., The Role of Social Drinking Motives in the Relationship Between 
unacceptable to gamble are similarly less likely to do so. ${ }^{130}$

Although people consciously observe the behavior of others to determine how to act in social situations, ${ }^{131}$ it is also true that some of this norm development can occur automatically and unconsciously. For example, when college dormitory residents received flyers in their school mailboxes, they were more likely to litter and throw the flyers on the floor when the mailroom floor was covered with other flyers and less likely when the floor was clean. ${ }^{132}$ Interestingly, they were least likely to litter when the floor was clean, except for "one piece of highly conspicuous litter (a hollowed-out, end piece of watermelon rind)." "133 The students behaved in an orderly way because the environment reminded them that the norm was that "everybody behaved orderly except for "the pig that spoiled the place." 134 Similarly, people who were shown a picture of a library spoke more quietly because of the situational norm that people unconsciously associate with libraries. ${ }^{135}$

When people have simultaneous, yet incompatible beliefs, the tension that results is known as cognitive dissonance. ${ }^{136}$ Dissonance occurs in both individuals and in social groups; when people evaluate their own behavior and find it different from some standard of judgment they experience cognitive dissonance. ${ }^{137}$ That standard of judgment can be personal to the individual ("I think it is important to respect the environment but I drive an SUV"), or it can be

Social Norms and Alcohol Consumption, 37 AdDICTIVE BeHAV. 1135, 1338 (2012).

130. Mary E. Larimer \& Clayton Neighbors, Normative Misperception and the Impact of Descriptive and Injunctive Norms on College Student Gambling, 17 PSYCHOL. ADDICTIVE BEHAV. 235, 241 (2003).

131. Henk Aarts \& Ap Dijksterhuis, The Silence of the Library: Environment, Situational Norm, and Social Behavior, 84 J. Personality \& Soc. Psychol. 18, 18-19 (2003). Situational norms are defined as "knowledge or mental representations of appropriate behavior that can be accessed to guide behavior in a specific situation or environment." Henk Aarts et al., Automatic Normative Behavior In Environments: The Moderating Role Of Conformity In Activating Situational Norms, 21 Soc. CoGNition 447, 448 (2003).

132. Robert B. Cialdini et al., A Focus Theory of Normative Conduct: Recycling the Concept of Norms to Reduce Littering in Public Places, 58 J. PersonAlity \& Soc. PsyCHOL. 1015, 1019 (1990).

133. Id.

134. Aarts \& Dijksterhuis, supra note 131, at 19 (discussing Cialdini et al., supra note 132).

135. Id. at 19-20. As the authors note, however, "this effect was qualified by the presence of the goal to go to the library." $I d$. at 24 . In other words, if people who saw the picture did not expect to visit a library, they did not speak in quieter voices. $I d$. at 24.

136. Jennifer K. Robbenolt \& JeAn R. Sternlight, Psychology For LAwyers: UNDERSTANDING THE HuMAN FACTORS IN NEGOTIATION, LiTigATION, AND DECISION MAKING 20 (2012). One of the earliest descriptions of cognitive dissonance explains that " $[\mathrm{t}] \mathrm{he}$ presence of dissonance leads to action to reduce it just as, for example, the presence of hunger leads to action to reduce the hunger." LeOn Festinger, A THEORY OF Cognitive Dissonance 18 (1962).

137. David C. Matz \& Wendy Wood, Cognitive Dissonance in Groups: The Consequences of Disagreement, 88 J. Personality \& Soc. Psychol. 22, 22 (2005). 
external to the individual and based on social norms ("I am a member of the Catholic Church but I believe religious employers should provide birth control to employees.").

People often experience significant discomfort when their behavior or opinions are different from the group, and this discomfort can motivate individuals to change their own beliefs to conform to those of the group. ${ }^{138}$ For example, in one study subjects were asked their individual opinions on a variety of social issues. ${ }^{139}$ They were then placed in a group and given the other group members' responses to the same questions. ${ }^{140}$ Those who were grouped with others with different opinions experienced significant amounts of dissonance (specifically they were "uncomfortable and tense"), especially when they were expected to interact with the group, or to interact until they reached a consensus on the issues. ${ }^{141}$

Going against the norm in a group can be so difficult that it actually triggers activity in areas of the brain associated with negative mental states. ${ }^{142}$ In a recent study testing this effect, researchers used functional magnetic resonance imaging ("fMRI") to monitor participants' neuronal activity while they completed a task. ${ }^{143}$ Participants were shown two pairs of three-dimensional objects and asked to "mentally rotate" them to decide if they were identical. ${ }^{144}$ Before making their decisions, they were told about the decisions of a group of peers, whose answers were incorrect half of the time. ${ }^{145}$ When participants disagreed with the group - even when the group's answers were wrong - there was increased activity in the amygdala region of the brain, which is closely associated with negative emotional states. ${ }^{146}$ As the authors noted, "[t]he amygdala activation in our experiment was perhaps the clearest marker of the emotional load associated with standing up for one's belief."147

138. Michael I. Norton et al., Vicarious Dissonance: Attitude Change From the Inconsistency of Others, 85 J. PERSONALITY \& SOC. PSYCHOL. 47, 58-59 (2003).

139. Matz \& Wood, supra note 137, at 25. Specifically, subjects were asked for their opinions on seven social or campus issues: "capital punishment, immigration laws, legalized abortion, tuition increases to provide funding to attract minority students, a law to make flag burning illegal, gun control, and reinstating a university-wide bonfire celebration that had been terminated because of safety concerns." Id.

140. Id. at 24-25.

141. Id. at 27. Subjects also experienced a lesser degree of discomfort when they were simply told about other group member's differing opinions, but did not expect to interact with the other group members. $I d$. The same study found similar levels of dissonance and discomfort when mock jurors disagreed with other members of the jury. Id. at 29.

142. Berns et al., supra note 57, at 252.

143. Id.

144. Id. at 246-47 (Figure 1).

145. $I d$. at 245 .

146. $I d$. at 252 .

147. Id. Interestingly, the "amygdala is also known to modulate social behavior and to be activated by human faces, particularly when the faces have emotional significance." Id. (citing 
Conversely, when a group has a mutual understanding of the applicable norms - when everyone knows and agrees about what everyone else is supposed to do-group performance improves. ${ }^{148}$ In a study of physicians and nurses working in an emergency room, nurses were asked how "frequently work problems in their units were solved by 'having clear and detailed job definitions for all involved."'149 Researchers then measured various indicators of effective care within the hospital, including the promptness of care, the quality of nursing care, and the quality of medical care. ${ }^{150}$ As normative consensus increased, specifically when nurses felt everyone agreed about work expectations in the emergency room, all of the indicia of effective care correspondingly increased. ${ }^{151}$ As the authors noted, "[w]hen agreement about norms exists ... [t]his provides a base for coordination and for effective performance."152

One of the benefits of the jury system is that jurors incorporate community values and community norms. ${ }^{153}$ The jury defines the appropriate standard of care in a given situation, or it decides what amount of damages will make an injured person whole. ${ }^{154}$ These are not specific standards, and the jury is expected to be a representative of the community in making these sorts of normative assessments. ${ }^{155}$ Norms are central to the entire concept of a representative jury: "only a body taken from a cross sectional representative group of the community can meaningfully project community norms." 156 If individual jurors are unwilling to stand up to the majority, however, or to act in a way that conflicts with the norms of the group, this unwillingness undermines the benefits of the representative jury and can lead to decisions based on the beliefs of a few individual jurors, rather than the decisions of a diverse group of decisionmakers.

\section{Roles}

On January 13, 1982, Air Florida Flight 90 took off from National Airport in

various studies).

148. Linda Argote, Agreement About Norms and Work-Unit Effectiveness: Evidence From the Field, 10 BASIC \& APPLIED SOC. PSYCHOL. 131, 132 (1989). The study relied on interviews and questionnaires of 248 emergency unit physicians, 278 nurses, and 215 hospital physicians in six Midwestern states. Id. at 133.

149. Id. at 134 .

150. Id. at 132 .

151. Id. at 138. As the authors note, however, "[ $\mathrm{t}]$ his agreement is likely to vary across systems. For example, in one hospital, nurses might think that what administrators expect the nurses to do is "about right," whereas in another, nurses might think administrators expect the nurses to do too much paperwork or to exert too little influence over patient care." Id. at 132 .

152. Id. at 137 .

153. RANDOLPH N. JonAKAIT, THE AMERICAN JURY SySTEM 64-66 (2003).

154. Id. at 64-66.

155. Id. at 72 .

156. Gary Goodpaster, On the Theory of American Adversary Criminal Trial, 78 J. CRIM. L. \& CRIMINOLOGY 118, 146 (1987). 
Washington, D.C. en route for Fort Lauderdale, Florida. ${ }^{157}$ There had been a snowstorm that morning, with approximately four to eight inches of snow in the Washington area and the flight was delayed for almost two hours. ${ }^{158}$ There were seventy-four passengers and five crewmembers on board the flight. ${ }^{159}$ When the plane did take off, it was unable to gain proper speed due to ice on the wings and crashed over the Fourteenth Street Bridge and into the Potomac River. ${ }^{160}$ Only five of the people on the plane survived, and the crash also killed four commuters on the bridge, bringing the death toll to seventy-eight. ${ }^{161}$

Although the plane had been cleared for takeoff, the final decision to fly rested with the pilot. ${ }^{162}$ The official National Transportation Safety Board Report blamed ice on the wings for the crash, and specifically the crew's failure to de-ice the wings prior to takeoff. ${ }^{163}$ The pilot and the first officer had run through the standard pre-flight checklist, and although the first officer had noticed extra ice building up on the wings and questioned the pilot, the pilot dismissed his concerns and they continued with the takeoff. ${ }^{164}$ The pilot and the first officer "had adopted such a fixed pattern of role responsibilities in their pre-flight checks that they failed to notice a serious build up of ice on the aircraft's wings and thus omitted to activate the deicing devices that were available to deal with the problem." 165

As part of his "role" as pilot, the pilot on Flight 90 decided to fly the plane, even though the first officer felt there might be a problem with ice on the wings. ${ }^{166}$ A "role" is a set of behaviors expected of people who occupy a certain position within a group of social situation ${ }^{167}$-pilots fly planes, doctors see patients, and waiters serve food. Like norms, roles are sometimes deliberately created - an employer appoints a manager or a jury elects a foreperson —or they can develop more organically. Even without a deliberate assignment of roles,

157. Kevin Ambrose, The 30 Year Anniversary of the Crash of Air Florida Flight 90, WASH. Post, (Jan 13, 2012, 4:55 AM), http://alturl.com/exs8n, archived at http://perma.cc/393M-P69A.

158. Connie J. G. Gersick \& J. Richard Hackman, Habitual Routines in Task-Performing Groups, 47 Org. BeHAV. \& Hum. Decision Processes 65, 65 (1990).

159. $I d$.

160. Ambrose, supra note 157.

161. Id.

162. Id.

163. Gersick \& Hackman, supra note 158 , at 65.

164. Id. at 66-67.

165. BROWN, supra note 114 , at 71.

166. Ambrose, supra note 157; see also Gersick \& Hackman, supra, note 158, at 66-67 (expressing the hesitancy of the first officer).

167. Brown, supra note 114, at 149; see also Travis C. Tubre \& Judith M. Collins, Jackson and Schuler (1985) Revisited: A Meta-Analysis of the Relationships Between Role Ambiguity, Role Conflict, and Job Performance, 26 J. MGMT. 155, 155 (2000) ("a role is defined at a pattern of behaviors"); Ann Bettencourt \& Kennon Sheldon, Social Roles as Mechanisms for Psychological Need Satisfaction Within Social Groups, 81 J. Personality \& Soc. Psychol. 1131, 1132 (2001) (noting that "social roles are typically associated with duties, norms, and expectations"). 
however, groups usually develop some sort of informal role structures through the process of role differentiation, with roles eventually becoming more narrowly defined and specialized. ${ }^{168}$

Discrete and clear-cut roles within groups can help give structure and order to groups and also help people form identities within the group. ${ }^{169}$ But sometimes roles within the group can be ambiguous where the responsibilities required of the role are not clear to the person occupying it or other members of the group. ${ }^{170}$ Or there may be poor "role fit" where the behaviors associated with the role do not match the personal characteristics of the person who occupies the role. ${ }^{171}$ Role ambiguity and poor role fit can result in stress and tension for all group members and lead to poor group performance. ${ }^{172}$ Overall, groups tend to perform better-they make better choices and work more efficiently-when group members share the same ideas about their task and the role they each play in the group. ${ }^{173}$

The role of the leader is a fundamental one in many groups, and the role of the foreperson is a significant one in juries. ${ }^{174}$ In some states and in some federal jurisdictions, the trial judge commonly appoints the foreperson, and in three states - Maryland, Massachusetts and Rhode Island - the judge is required to do so. ${ }^{175}$ When the jury elects the foreperson, however, that person tends to be

168. BROWN, supra note 114 , at 150.

169. Id. at 72 .

170. Mark R. Beauchamp et al., Role Ambiguity, Role Efficacy, and Role Performance: Multidimensional and Meditational Relationships Within Interdependent Sport Teams, 6 GROUP DYNAMICS: THEORY, RES., \& PRAC. 229, 229 (2002) ("Role ambiguity refers to a lack of clear information associated with a particular role.").

171. Bettencourt \& Sheldon, supra note 167, at 1140 (defining "role-fit" as the "correspondence between role requirement and person characteristics.").

172. Mark R. Beauchamp \& Steven R. Bray, Role Ambiguity and Role Conflict Within Interdependent Teams, 32 SMALL GROUP RES. 133, 148 (2001) (finding that elite university athletes in interdependent sports teams - "elite sport teams characterized by a high degree of interdependence (such as hockey, rugby, soccer, and basketball) in which members' role-related functions are likely to be prevalent, identifiable, and highly integrated with those of other team members" - with greater levels of role ambiguity had worse performance); see also Bettencourt \& Sheldon, supra note 167, at 1140 (finding that the "degree to which an assigned role corresponded with a person's strengths and characteristics influenced experiences of authenticity and connectedness while playing the role.").

173. John E. Mathieu et al., The Influence of Shared Mental Models on Team Process and Performance, 85 J. APPLIED PSYCHOL. 273, 279-80 (2000).

174. BROWN, supra note 114, at 150.

175. Andrew Horwitz, Mixed Signals and Subtle Cues: Jury Independence and Judicial Appointment of the Jury Foreperson, 54 CATH. U. L. REV. 829, 830 (2005). As Horwitz points out, this practice is problematic for a variety of reasons: Unlike the much more traditional practice of allowing the jury to elect its own foreperson, judicial appointment of the foreperson is fraught with a variety of serious infirmities, many of them of constitutional magnitude. A substantial body of case law and literature - as well as common sense - tells us that anything that a trial judge says or 
white, male, and seated at the end of the table. ${ }^{176}$ The foreperson has often had, or claims to have had, prior jury experience ${ }^{177}$ and is usually the first person to mention the need for a foreperson. ${ }^{178}$

A recent study of mock juries found that even where there were an almost even number of men and women on juries, only two of the fourteen nominated forepersons were woman and the remaining twelve were men. ${ }^{179}$ Speaking first is often a strong predictor of who is chosen as foreperson, but this study found that most of the time when women spoke first, it was to nominate a male member of the jury as foreperson. ${ }^{180}$ Young people are also underrepresented as foreperson: while forty-two percent of jurors were between eighteen and thirtyfive years of age, only twenty-four percent of elected forepersons were, and sixtyfive percent of forepersons were between forty-five and sixty-five years of age. ${ }^{181}$ Extroverted jurors are more likely to be elected foreperson, ${ }^{182}$ as are those with more education and higher social economic status. ${ }^{183}$ Most of the time,

does during a trial is likely to be perceived by all of the trial participants, including the jurors, as a reflection of the judge's personal views and opinions.

176. HASTIE ET AL., supra note 51, at 28 (1983); see also VIDMAR \& HANS, supra note 2, at 143 (noting that when jurors select the foreperson, "it tends to be a person who is high in social status, has a college degree, and has experience in group settings, leadership positions, or prior jury service. Women are less likely to be chosen than would be expected from their representation on the jury."); Phoebe C. Ellsworth, Are Twelve Heads Better Than One?, 52 LAW \& CONTEMP. PROBS. 205, 214 (1989) (noting that seat location is often explicitly given as a reason for the selection of the foreperson: "In the majority of cases the jurors explicitly gave table position as their reason for their choice - 'you should do it, you're sitting in the right place."').

177. Devine et al., supra note 19, at 696; see also Ellsworth, supra note 176, at 213. Ellsworth describes the typical conversation that occurs during the selection of the foreperson: $I d$. When the jurors had arrived in the room and settled in their seats, someone would point out that their first job was to choose a foreman, and then typically someone would ask, "Has anybody had any experience with this sort of thing?" Id. A man would claim experience, and the other jurors would agree that he should take the job. Id. Occasionally, two men would claim experience and a brief "after you, Alphonse" discussion would ensue until one of them said, "all right, I'll do it." Id. These two scenarios account for foreman selection in ten of the eighteen juries. Id. Of course, as Ellsworth notes, the person selected did not always have jury experience. $I d$. In this study, thirty-nine percent of the foremen selected had served on juries, while thirty-six percent of other jurors who were not elected also had previous jury experience, an insignificant difference. Id.

178. Devine et al., supra note 19, at 696.

179. Louise Ellison \& Vanessa E. Munro, Getting to (Not) Guilty: Examining Jurors' Deliberative Processes in, and Beyond, the Context of a Mock Rape Trial, 30 LEGAL STUD. 74, 89 (2010). Moreover, the two women who were selected foreperson nominated themselves. Id.

180. Id.

181. Id.

182. John Clark et al., Five Factor Model Personality Traits, Jury Selection, and Case Outcomes in Criminal and Civil Cases, 34 CRIM. Just. \& BeHAV. 641, 644 (2007).

183. Shari Seidman Diamond \& Jonathan D. Casper, Blindfolding the Jury to Verdict Consequences: Damages, Experts, and the Civil Jury, 26 LAW \& SoC'Y REV. 513, 549 (1992). 
foreperson selection occurs in the first four minutes of deliberation and within ten or twenty statements by jurors. ${ }^{184}$ As noted above, not all jurors participate equally, and the foreperson tends to talk two to three times more than other jurors. ${ }^{185}$

The roles that individuals have in the group can have a significant impact of the quality of the jury's deliberation and decisionmaking. If jurors are uncertain about their roles because of role ambiguity or poor role fit, this uncertainty can lead to stress and tension among jury members and poorer performance. ${ }^{186}$ This result is especially likely in juries, because of the high degree of task interdependence: each individual juror's role in the deliberative process is dependent and interwoven with other jurors' roles. ${ }^{187}$ For example, in one study, college athletes with high role ambiguity - specifically they were unsure of the scope of their responsibilities on the team-played more poorly than other players. ${ }^{188}$

Because the role of foreperson is an important one with significant impact on the form and content of deliberation, choosing a foreperson because they are white, male, older, or more extraverted, is in stark contrast to the ideals of a representative jury. We should give jurors additional information about the important role the foreperson plays; this additional information will help all jurors cope with role stress by making the duties of the foreperson and the behavior associated with them more explicit. ${ }^{189}$

\section{The Role OF SOCIAL INFLUENCE ON JURY DECISIONMAKING}

We trust groups of jurors with decisionmaking because we think that the diversity of the group and the resources of its individual members will lead to improved decisionmaking, that "two heads are better than one." Moreover, jury diversity is an important part of the representative jury system and gives heightened legitimacy to the legal process. Many studies highlight the benefits of diverse juries: juries composed of diverse members deliberate longer and consider more information than juries that are less diverse. ${ }^{190}$ In one recent study

184. Ellison \& Munro, supra note 179, at 88; Diamond \& Casper, supra note 183, at 547.

185. HASTIE ET AL., supra note 51, at 28.; Ellison \& Munro, supra note 179, at 88.

186. Beauchamp et al., supra note 170, at 229.

187. Id. (explaining that "when role occupants' responsibilities are interwoven with those of other individuals in an organizational system, the impact of role ambiguity on the role occupant personally should be more problematic compared with when role occupants function more or less independently of others. Furthermore, in situations characterized by interdependence of roles, ambiguity could be predicted to influence the thoughts and behaviors of both the role occupant and the other individuals (e.g., group members) with whom he or she interacts.").

188. Id. at 238.

189. Robert D. Pritchard et al., The Productivity Measurement and Enhancement System: A Meta-Analysis, 93 J. APPLIEd Psychol. 540, 558 (2008); see also infra Part IV.C.

190. Samuel R. Sommers, On Racial Diversity and Group Decision Making: Identifying Multiple Effects of Racial Composition on Jury Deliberations, 90 J. PERSONALITY \& SOC. PSYCHOL. 
of mock juries, white jurors "raised more case facts, made fewer factual errors, and were more amenable to discussion of race-related issues when they were members of a diverse group." ${ }^{191}$ Diversity also improves creativity within the group, flexibility in decisionmaking, and thoughtfulness. ${ }^{192}$

But relying on diverse groups of individuals to reach decisions about difficult topics has its drawbacks. When people become members of a jury, individual jurors lose some of their independence and must coordinate their actions with other jurors. While particular jurors may have greater or less influence over the group because of group dynamics like status, norms, and roles, the group itself still has a profound influence on those individual jurors. This type of social influence - or the "interpersonal processes that produce, sometimes directly but often very subtly and indirectly, changes in other people"-flows from the group to the individual, and from the individual to the group. ${ }^{193}$ Jurors may feel pressure to modify their opinions and judgments to conform to the majority of other jurors. Relatedly, jurors may experience certain motivation losses, like "social loafing" and the "free-rider effect" when they are acting as a group because they do not feel the same responsibility to act as they would if they were acting alone. ${ }^{194}$ We can examine group conformity and motivation losses among groups to get a better sense of how these group dynamics influence jury deliberation and decisionmaking.

\section{A. Group Conformity}

"We are discreet sheep; we wait to see how the drove is going, and then go with the drove."

-Mark Twain ${ }^{195}$

Although people tend to explain behavior in terms of individual personalities, social situations also have a profound influence on human behavior and individuals are often quick to conform to the behavior of others. ${ }^{196}$ In a series of famous experiments testing behavior in a group setting, Solomon Ashe asked

597, 606 (2006).

191. Id. In this case, "diversity" meant there were four whites and two blacks in each of the six-member juries. Id. at 601 . A variety of studies support the idea that diversity leads to better group performance. See, e.g., Karen A. Jehn et al., Why Differences Make a Difference: A Field Study of Diversity, Conflict, and Performance in Workgroups, 44 ADMIN. SCI. Q. 741, 757 (1999).

192. Sommers, supra note 190, at 598 (citing various studies). At the same time, some studies suggest that "diversity creates social divisions that, in turn, create poor social integration and cohesion, resulting in negative outcomes for the group." Elizabeth Mannix \& Margaret A. Neale, What Differences Make a Difference? The Promise and Reality of Diverse Teams in Organizations, 6 PSYCHOL. SCI. PUB. INT. 31, 34 (2005).

193. FORSYTH, supra note 64, at 178.

194. Henningsen et al., supra note 1 , at 168 .

195. MARK TWAIN's AUTOBIOGRAPHY VOL. II, 10 (1924).

196. FISKE, supra note 24, at 7. 
groups of college students to participate in what they were told was an experiment testing perception. ${ }^{197}$ Subjects were asked to compare the length of a "standard" line against three "comparison lines." 198 One of the comparison lines was the same as the standard line, while the other two were much longer or much shorter. ${ }^{199}$ Unbeknownst to the real subjects in the study, the other members of the group were instructed to give the same wrong answer before the subject gave his own answer. ${ }^{200}$ After hearing the confederate's incorrect answer, seventy-five percent of participants went along at least once with the confederate's mistakes, which were obvious errors of half an inch to three-quarter of an inch on lines that were anywhere between two and ten inches. ${ }^{201}$ In contrast, when subjects were asked to make independent judgments, they were correct over ninety-nine percent of the time. ${ }^{202}$ On average, participants in the experimental groups were wrong a third of the time, with no other cause than conformity to the group- the social situation - and "contradicting the clear evidence of his senses." 203

Although the conformity seen in Ashe's studies was extreme, people conform their behavior to that of others in group settings all of the time, sometimes without even realizing they are doing so. ${ }^{204}$ When we observe the actions of others, it actually triggers the same neurophysiological response as if we took the action ourselves. ${ }^{205}$ "Mirror neurons" in the frontal lobes of monkeys discharge when the monkey grasps a piece of food and when it watches another monkey make a similar grasping motion. ${ }^{206}$ Similar research of human fMRIs shows that

197. Solomon E. Ashe, Studies of Independence and Conformity: A Minority of One Against a Unanimous Majority, 70 PsYCHOL. MONOGRAPHS 1, 3 (1956).

198. Id. at 3 .

199. The standard line varied from two to ten inches, and the comparison lines differed from the standard lines by $1 / 2$ to $1 \frac{3 / 4}{4}$ inches, as indicated in this example from the study:

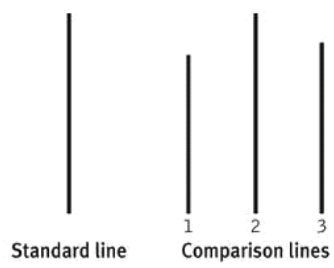

Id. at 6 , Table 1.

200. Id. at 3 .

201. Id. at 9 .

202. Id. at 3 .

203. Id.

204. FORSYTH, supra note 64, at 196.

205. GÜn R. Semin, Grounding Communication: Synchrony, in Social Psychology: HANDBOOK OF BASIC PRINCIPLES 632-33 (Arie W. Kruglanski \& Tory Higgins eds., 2007).

206. Vittorio Gallese et al., Action Recognition in the Premotor Cortex, 119 BRAIN 593, 593 (1996). 
the premotor cortex is active when people watch other people act. ${ }^{207}$ The mind creates a "neural replica" of the observed action- "that is, the regions activated correspond to those that are active during the execution of the action." ${ }^{208} \mathrm{We}$ mimic the facial expressions of the people around us, as well as their motor behavior, accents, speech rhythms, and moods. ${ }^{209}$ Human beings are social animals and this type of social coordination with the group is necessary for survival. ${ }^{210}$

People also compare their opinions to the people around them and evaluate the accuracy of their own beliefs and decisions in comparison to those of the group. $^{211}$ Like other individual decisions, groups make decisions and interpret information along a continuum from quick intuitive judgments to slower, more thoughtful reasoning. ${ }^{212}$ Groups, like individuals, sometimes rely on "fast," or intuitive, categorical thinking, and they are also sometimes more systematic, or "slow" in their thinking. ${ }^{213}$ In the jury setting, jurors might not pay attention to

207. G. Buccino et al., Action Observation Activates Premotor and Parietal Areas in a Somatotopic Manner: An fMRI Study, 13 EUR. J. Neuroscience 400, 401 (2001). There is, however, a recent debate in the neuroscience literature about these findings. See Gregory Hickok, Eight Problems for the Mirror Neuron Theory of Action Understanding in Monkeys and Humans, 21 J. Cognitive NeuroscienCE 1229, 1240 (2008) (suggesting that "the 'mirror system' is not the basis for action understanding").

208. SEMIN, supra note 205, at 633.

209. Simone Kühn et al., Why Do I Like You When You Behave Like Me? Neural Mechanisms Mediating Positive Consequences of Observing Someone Being Imitated, 5 SOC. NEUROSCIENCE 384, 384 (2010).

210. Patrick Bourgeois \& Ursula Hess, The Impact of Social Context on Mimicry, 77 BiologicAl Psychol. 343, 343 (2008).

211. FORSYTH, supra note 64, at 196.

212. See Serena Chen et al., Motivated Heuristic and Systematic Processing, 10 Psychol. INQUIRY 44 (1999) (citing various studies); see also GORDON B. MOSKOWITZ, SOCIAL COGNITION: UNDERSTANDING SELF AND OTHERS 194 (2005) (describing the dual-process model coined by Marilynn Brewer. There are a variety of dual-process models, including Brewer's dual-process model, the heuristic-schematic model coined by Shelley Chaiken, and the theory of lay epistemics developed by Arie Kruglanski. The various models use different terminology, but all of them describe people as using a combination of default information processing including schemas and heuristics, as well as more effortful and deliberate mental processing. For a review of the various models, see id. at 195-219.

213. Daniel Kahneman refers to these two ways of thinking as System One and System Two reasoning. Daniel Kahneman, Maps of Bounded Rationality: Psychology for Behavioral Economics, 93 AM. ECON. REV. 1449, 1451 (2003). In System One, or heuristic reasoning, groups make decisions quickly, and often base those decisions on instincts, emotions, schemas, or stereotypes. This type of "fast thinking" has evolved because people and groups need to manage a complex environment with limited cognitive resources. Id. (describing the operations of System One as "fast, automatic, effortless, associative, and often emotionally charged; they are also governed by habit, and are therefore difficult to control or modify."). In contrast, System Two, or systematic reasoning, relies on deliberate and reflective cognition, where groups take their time and 
the discussion, not really understand the arguments, or forget what others say, all of which can trigger "fast" thinking. ${ }^{214}$ Studies have shown that group members often base their decision on the general mood of the group instead of the quality of the arguments, ${ }^{215}$ and they are more willing to believe a minority view when the person speaks more abstractly and avoids specifics. ${ }^{216}$ Another shortcut individuals use is preference for the popular choice: people look to others' choices in deciding how to invest their money, how many children to have, and whether to adopt new technology. ${ }^{217}$ This phenomenon is known as "herding," and it has a rational basis: "paying heed to what everyone else is doing is rational because their decisions may reflect information that they have and we do not." 218

The influence of the majority in jury deliberations also depends on these types of cognitive shortcuts or heuristics. If jurors think that the minority view is becoming more popular with other jury members, they may shift sides. In one study, subjects were given a five-page summary of the trial and jury deliberations in the movie Twelve Angry Men. ${ }^{219}$ First, the subjects were told that the jury vote was eleven against one to convict the defendant. ${ }^{220}$ When the subjects were asked to rate the guilt of the defendant after that first vote, almost all of them agreed with the majority. ${ }^{221}$ But when subjects were subsequently told that after deliberations progressed, the jury's vote began shifting toward not guilty, the subjects shifted their own votes from guilty to not guilty. ${ }^{222}$ As the authors noted, "participants were influenced by both majority defection to the minority position and the number of persons who presented arguments for the minority position."

think carefully and slowly about evidence before reaching a decision. Id. (describing the operations of System Two as "slower, serial, effortful, and deliberately controlled; they are also relatively flexible and potentially rule-governed."). Of course, not all "fast" decisionmaking is bad decisionmaking. For a discussion of the benefits of intuitive thinking in judicial decisionmaking, see Linda Berger, A Revised View of the Judicial Hunch, 10 LEGAL COMM. \& RHETORIC: JALWD 1 (2013).

214. FORSYTH, supra note 64, at 198.

215. Eddie M.W. Tong et al., Conformity: Moods Matter, 38 EuR. J. Soc. PsychOL. 601, 607 (2008). As the authors note, good moods are associated with System One/heuristic thinking, while bad moods are more associated with System Two/deliberative thinking. Id. at 602 (citing various studies).

216. Harold Sigall et al., Minority Influence Is Facilitated When the Communication Employs Linguistic Abstractness, 9 GROUP PROCESSES \& INTERGROUP REL. 443, 449 (2006) (noting that "no such effect occurred when the communicator represented the majority").

217. Abjihit Banerjee, A Simple Model of Herd Behavior, 107, Q. J.ECON. 797, 797-98 (1992).

218. Id. at 798 .

219. Russell D. Clark III, Effects of Majority Defection and Multiple Minority Sources on Minority Influence, 5 Group DyNAMICS: THEORY, RES., \& PRAC. 57, 59 (2001).

220. Id. at 59 .

221. Id. at 59-61.

222. Id. The subjects were told that after deliberations, the jury's vote shifted from nine to three to convict, and then to six to six, to three to nine, and eventually to zero to twelve. $I d$.

223. Id. at 60 . 
Diverse groups of individuals bring different life experiences and backgrounds to the jury, but are also susceptible to social influence and will tend to conform their beliefs and behaviors to other members of the jury. ${ }^{224}$ This social influence has an especially significant effect when individual jurors are in the minority. The tendency to conform to the group and to rely on cognitive shortcuts means that the minority view can often go unmentioned and unexamined in the context of group deliberations.

\section{B. Social-Loafers and Free-Riders}

"Got a good reason

For taking the easy way out now."

-John Lennon \& Paul McCartney, Day Tripper ${ }^{225}$

Although juries often possess tremendous resources, including the background and experiences of individual jurors, they do not always use the resources of their individual members effectively. ${ }^{226}$ In juries, as in all groups, productivity is often lower than the potential productivity of individual members because of both "coordination losses" and "motivation losses." ${ }^{227}$ Coordination losses, or "productivity losses," occurs in groups because by their very nature groups allow for only one person to talk at a time and other members cannot (or usually should not) speak during that time. ${ }^{228}$ This aspect of group decisionmaking prohibits individuals from speaking about their ideas as they occur, especially if other members of the group are dominating the conversation. $^{229}$ Those ideas may then be forgotten, or dismissed, as the individual listens to other members of the group. ${ }^{230}$ Motivation losses, on the other hand, occur for a variety of reasons, but can be broadly categorized as the

224. Id at 58 .

225. John LenNON \& PAUl MCCARTNEY, DAy TRIPPER (EMI Studios 1965).

226. Henningsen et al., supra note 1, at 168. Recent studies on "brainstorming," for example, suggest that people who brainstorm alone come up with more ideas - and more good ideas - than people who brainstorm in groups. See Nicholas W. Kohn \& Steven M. Smith, Collaborative Fixation: Effects of Others' Ideas on Brainstorming, 25 APPLIED COGNITIVE PSYCHOL. 359, 359 (2011) (citing various studies).

227. The most often cited description of this process is Steiner's work on "process losses" in groups. See IVAn D. Steiner, Group Process AND Productivity (1972). For a more recent review, see Henningsen et al., supra note 1, at 168.

228. Henningsen et al., supra note 1, at 168.

229. Id.

230. Bernard A. Nijstad et al., Cognitive Stimulation And Interference In Groups: Exposure Effects In An Idea Generation Task, 38 J. EXPERIMENTAL Soc. PsychOL. 535, 537 (2002). For an application of the theory to intelligence analysis teams, see Susan G. Straus et al., The Group Matters: A Review of Processes and Outcomes in Intelligence Analysis, 15 GrouP DYNAMICS: THEORY, RES., \& PRAC. 128, 131 (2011). 
problems of social loafing and free-riding. ${ }^{231}$

When people work alone, they often work harder than when they work in groups. ${ }^{232}$ When people work in groups, some group members reduce their own efforts because they assume that other members of the group will put forth the necessary effort to complete the assigned task. ${ }^{233}$ This phenomenon, known as "social loafing," is true across a variety of tasks. ${ }^{234}$ Social loafing occurs in tasks requiring physical effort like rope-pulling and cheering, as well as in tasks requiring cognitive effort like brainstorming and writing poems. ${ }^{235}$ Students are often implicitly aware of this phenomenon: because they think that other group members will not do their share of the work, students often prefer courses where individual efforts toward group work is counted in the grade, and avoid those courses where all group members receive the same grade on the project. ${ }^{236}$ This loafing occurs - at least in part - because when the group's efforts are combined, individual effort becomes lost. "Because participants can receive neither credit nor blame for the individual performances, they loaf." ${ }^{237}$

Groups that are less cohesive tend to have higher instances of social loafing and poorer performance overall. ${ }^{238}$ Social loafing in less cohesive groups is present in cognitive tasks ${ }^{239}$ and physical tasks, ${ }^{240}$ and has also been seen in creative partnerships as well, like songwriting and filmmaking. For example, one study considered the quality and creativity of 162 Beatles songs written by John Lennon and Paul McCartney. ${ }^{241}$ Researchers found that for songs written before

231. Kerr \& Tindale, supra note 56, at 628.

232. Id. at 625; see also Kenneth H. Price et al., Withholding Inputs in Team Contexts: Member Composition, Interaction Processes, Evaluation Structure, and Social Loafing, 91 J. APPLIED PSYCHOL. 1375, 1375 (2006).

233. Henningsen et al., supra note 1, at 168.

234. $I d$.

235. For a comprehensive review of the original social loafing literature, see Steven J. Karau \& Kipling D. Williams, Social Loafing: A Meta-Analytic Review and Theoretical Integration, 65 J. Personality \& Soc. Psychol. 681 (1993). For a more recent review, see Ashley Simms \& Tommy Nichols, Social Loafing: A Review of the Literature, 15 J. MGMT. Policy \& PRACTICE 58, 65 (2014).

236. Jody R. Hoffman \& Steven G. Rogelberg, All Together Now? College Students' Preferred Project Group Grading Procedures, 5 Group DynAmics: THEORY, ReS., \& PraC. 33, 38 (2001).

237. Stephen G. Harkins \& Jeffrey M. Jackson, The Role of Evaluation in Eliminating Social Loafing, 11 PersonAlity \& SOC. PSYCHOL. Bull. 457, 458 (1985). The term "social loafing" was originally coined by Bibb Latané. See Bibb Latané et al., Many Hands Make Light the Work: The Causes and Consequences of Social Loafing, 37 J. PERSONALITY \& SOC. PSYCHOL. 822, 826 (1979).

238. Rune Høigaard et al., The Effect of Team Cohesion on Social Loafing in Relay Teams, 18 INT'L J. APPLIED SPORTS SCI. 59, 68 (2006).

239. Paul W. Mulvey \& Howard J. Klein, The Impact of Perceived Loafing and Collective Efficacy on Group Goal Processes and Group Performance, 74 ORGANIZATIONAL BEHAV. \& HuM. DECISION PROCESSEs 62, 84-85 (1998).

240. Høigaard et al., supra note 238, at 68.

241. Jeffrey M. Jackson \& Vernon R. Padgett, With a Little Help from My Friend: Social 
1967, individually written songs were less likely to be selected as singles and did not do as well on the Billboard charts. ${ }^{242}$ The situation was reversed, however, for songs written after 1967; at that point, songs that were solo-written were more popular. ${ }^{243}$ As the authors note, "during the 1966-1967 years profound changes occurred. Perhaps these resulted from experimentation with drugs and filmmaking, the death of their manager Brian Epstein, the appearance of Yoko Ono, the change from live performances to studio recording, or the realization that they had become the most popular rock group of the time." ${ }^{244}$ The researchers theorized that as Lennon and McCartney began growing apart, they had reduced cohesiveness and more opportunity for social loafing. ${ }^{245}$

Although social loafing can be detrimental to group performance, it has a rational basis. Social loafing often occurs because people feel that their individual contributions to a group effort will not be noticed or are not necessary for the group's success. ${ }^{246}$ If people do not think their individual contributions will be noticed - or missed - it is rational for them to reduce their own effort and leave the work to others. ${ }^{247}$ In the classic study of this effect, people participating in a tug-of-war performed at a fraction of their individual potential when they performed in groups. ${ }^{248}$ In other words, they reduced their efforts as the group size increased because they felt that other members would compensate for them. ${ }^{249}$

Closely related to the problem of social loafing is the problem of free-riders: if group members think their individual efforts will not be helpful to the group,

Loafing and the Lennon-McCartney Songs, 8 Personality \& Soc. Psychol. Bull. 672, 675 (1982). Prolific song-writers, Lennon and McCartney wrote a total of 162 songs as members of the Beatles: John Lennon wrote seventy songs individually, McCartney wrote forty five, and they collaborated on forty seven. $I d$.

242. Id.

243. Id.

244. Id. at 673-74.

245. Id. at 676. However, in another study of individual and group songwriting credits of Billboard number one songs in the United States from 1955 to 2009, researchers found that individual and group songs were equally represented at the top of the Billboard charts. Terry F. Pettijohn II \& Shujaat F. Ahmed, Songwriting Loafing or Creative Collaboration?: A Comparison of Individual \& Team Written Billboard Hits in the USA, 7 J. ARTICLES SUPPORT NULL HYPOTHESIS 1, 3 (2010) ("Individuals or groups may create musical hits and social loafing in groups may occur in certain situations, but not always.").

246. See Alan G. Ingham, The Ringelmann Effect: Studies of Group Size and Group Performance, 10 J. EXPERIMENTAL SOC. PSYCHOL. 371 (1974) (describing French agricultural engineer Max Ringelmann's original 1927 study).

247. Id.

248. Id at $371-72$ (explaining if individual performance is considered $100 \%$ of potential, participants performed at ninety-three percent of their potential in pairs, eighty-five percent of their potential in groups of three, and forty-nine percent of their potential in groups of eight).

249. Id. at 371-72. 
they have a tendency to "free-ride" off of the efforts of others. ${ }^{250}$ The main difference between social loafing and free-riding is that social loafers reduce their effort because it is not essential for the group's success, while free-riders do not contribute to the group's task at all. ${ }^{251}$ Many economists believe that because so few elections are close calls and because of the personal costs in terms of time and effort in going to the polls, "a rational individual should abstain from voting." 252 Similarly, because a listener receives the same benefit whether or not they donate money to public radio, "most donors should therefore choose to freeride." ${ }^{253}$ The free-rider effect tends to increase as groups grow larger, both because individual behavior is less noticeable in larger groups, ${ }^{254}$ and because individual members' perceptions of the utility of their contributions declines in bigger groups. ${ }^{255}$

Social loafing and free-riding can be reduced or even eliminated when individual contributions to a group effort are identifiable ${ }^{256}$ and when people feel their contributions are unique or indispensible. ${ }^{257}$ Individuals also loaf and freeride less in smaller groups, probably because they are more likely to feel their individual contributions are necessary for the group's success. ${ }^{258}$ Furthermore, people are generally more willing to work harder on a group task when they think their individual contributions will be helpful in reaching an outcome they find personally valuable. ${ }^{259}$ These "valuable outcomes" can be objective, like

250. Kameda et al., supra note 59, at 76.

251. Id.

252. Patricia Funk, Social Incentives and Voter Turnout: Evidence from the Swiss Mail Ballot System, 8 J. EUR. ECON. Ass'N 1077, 1077 (2010).

253. Lise Vesturlund, Why Do People Give? The Nonprofit Sector: A Research HANDBOOK 568, 572 (Walter W. Powell \& Richard Steinberg, eds., 2006).

254. Norbert L. Kerr \& Steven E. Bruun, Dispensability of Member Effort and Group Motivation Losses: Free-Rider Effects, 44 J. Personality \& Soc. Psychol. 78, 79 (1983).

255. Id. at 92. If group members become suspicious that some members are free-riding, they sometimes reduce their own effort to match that of the free-riders. Norbert L. Kerr, Motivation Losses in Small Groups: A Social Dilemma Analysis, 45 J. Personality \& Soc. Psychol. 819, 820-25 (1983). This reduction in effort is known as "the sucker effect," whereby other group members will reduce their own efforts instead of playing the "sucker." Id. As one study observed, "apparently, subjects sometimes preferred to fail at the task rather than be a sucker and carry a free rider." Id. A more recent study has shown that the sucker effect is strongest when individuals think other members of the group are competent to perform the task, but lazy. Jason W. Hart et al., Coworker Ability and Effort as Determinants of Individual Effort on a Collective Task, 5 GROUP DYNAMICS: THEORY, RES., \& PRAC. 181, 187 (2001).

256. Price et al., supra note 232, at 1379.

257. Kerr \& Bruun, supra note 254, at 92; Simms \& Nichols, supra note 235, at 65.

258. Tatsuya Kameda et al., Social Dilemmas, Subgroups, and Motivation Loss in TaskOriented Groups: In Search of an "Optimal” Team Size in Division of Work, 55 Soc. PSYCHOL. Q.47, 54 (1992) (concluding motivation peaked in four-person groups and declined in both smaller and larger groups).

259. Karau \& Williams, supra note 120 , at 156 . The authors termed this idea the "Collective 
receiving a paycheck, or subjective, like gaining satisfaction, a feeling of belonging, or a feeling of self-worth. ${ }^{260}$ Furthermore, much of people's selfconceptions derive from their membership in various groups. ${ }^{261}$ Because people generally want other people to view them positively, they are motivated to enhance their status in the group. ${ }^{262}$ When the group becomes a part of an individual member's identity, those individuals will work harder for the benefit of the group, individual productivity will increase and social loafing and freeriding will decrease. ${ }^{263}$

Just as conformity in groups can affect individual behavior and cognition, the productivity of individual group members is also influenced by the presence of the group. Although people tend to be less productive when they believe other members of the group will make up the difference, we can reduce social loafing and free-riding by making individual effort identifiable and making individuals accountable for their contributions to the group decision.

\section{ReCOMMENDATIONS: TRAINING BETTER JURORS}

"It's all to do with the training: you can do a lot if you're properly trained." -Queen Elizabeth II

Training - or "a systematic approach to learning and development to improve individual, team, and organizational effectiveness"-improves the performance of both individuals and groups. ${ }^{264}$ A meta-analysis of 165 studies found that training improves performance. ${ }^{265}$ Moreover, a vast scholarly literature analyzing effective training details its benefits to performance, in fields ranging from social and organizational psychology to human resource development and knowledge management. ${ }^{266}$ Studies show that training increases innovation, enhances strategic knowledge (knowing when to apply a specific knowledge or skill), and

Effort Model." Id. at 157.

260. Id.

261. Anderson \& Kilduff, supra note 89, at 295 (noting that "the implications of achieving high status in one's group are profound. Those higher in the social order tend to have more access to scarce resources; receive more social support; and enjoy better physical health, a longer life span, and better reproductive success.").

262. Id. at 297.

263. Nathan C. Pettit \& Robert B. Lount, Jr., Looking Down And Ramping Up: The Impact of Status Differences on Effort in Intergroup Contexts, 46 J. EXPERIMENTAL SOC. PSYCHOL. 9, 10 (2009).

264. Aguinis \& Kraiger, supra note 6, at 452-53.

265. Winfred Arthur Jr. et al., Effectiveness of Training in Organizations: A Meta-Analysis of Design and Evaluation Features, 88 J. ApPLIED PSYCHOL. 234 (2003). By one estimate, companies in the United States spent over 164 billion dollars in 2012 on training for employees. AMERICAN SOCIETY FOR TRAINING AND DEVELOPMENT, STATE OF THE INDUSTRY REPORT (2013), available at http://alturl.com/anwhk, archived at http://perma.cc/LJB9-TPQ6.

266. Aguinis \& Kraiger supra note 6, at 452. 
can improve cooperation and communication within groups, which can ultimately improve decisionmaking. ${ }^{267}$

Most scholars have recognized a causal link between a better decisionmaking process and better outcomes - " [a] 'better' process leads to a more advantageous result." 268 Yet jurors - who are asked to work with others to make incredibly important decisions - are given almost no instruction, let alone any sort of formal training in decisionmaking or group dynamics. And while many empirical studies have found that jurors are competent decisionmakers, ${ }^{269}$ often reaching the same or similar decisions as judges, some additional training could be enormously helpful in assisting jurors to overcome many of the challenges all groups face in coming to decisions. Furthermore, this training does not have to be extensive, nor should it replace the common-sense approach that we hope lay jurors will bring to their decisionmaking. Instead, some simple training in group decisionmaking and the common pitfalls associated with group dynamics can enhance the way lay jurors approach the information they hear during a trial and improve decisionmaking.

Many model jury instructions contain a short instruction to jurors about their "duty to deliberate." 270 For example, the Ninth Circuit Model Civil Jury Instructions say that after electing a foreperson, jurors should "discuss the case with ... fellow jurors to reach agreement if you can do so" and that the verdict must be unanimous. ${ }^{271}$ The instructions continue: "[e]ach of you must decide the case for yourself, but you should do so only after you have considered all of the evidence, discussed it fully with the other jurors, and listened to the views of your fellow jurors. Do not hesitate to change your opinion if the discussion persuades you that you should. Do not come to a decision simply because other jurors think it is right. $" 272$

Beyond this instruction, however, jurors are given little or no guidance about effective decisionmaking strategies, or strategies for working in a group. Working with a group of people to analyze complex information and reach a verdict requires skills, knowledge, and attitudes that many lay jurors do not possess. ${ }^{273}$ And while a group of diverse decisionmakers is an important part of the jury system, this group superiority is lost if some jurors do not discuss all of the relevant information or capitulate to the majority opinion without thoughtful deliberation. Furthermore, because jurors have diverse sets of knowledge,

267. Id. at 454-56.

268. Randall S. Peterson, A Directive Leadership Style in Group Decision Making Can Be Both Virtue and Vice: Evidence From Elite and Experimental Groups, 72 J. PERSONALITY \& SOC. PsYchOL. 1107, 1107 (1997).

269. See Robbennolt, supra note 32.

270. See 3.1 DutY TO DeLiBERATE, supra note 3.

271. Id.

272. Id.

273. Richard L. Moreland et al., Training People to Work in Groups, Social Psychological ApPlicAtions to Social IsSUES: ApPliCATIONS OF THEORY AND RESEARCH ON Groups 37, 39 (Tindale et al., eds., 1998). 
procedures that structure deliberations are especially important to increase information sharing and effective decisionmaking and even simple training and recommended procedures can improve performance. ${ }^{274}$

Like all human cognition, group decisionmaking involves acquisition and use of information and typically involves four phases, which we can apply to jurors: accumulation, interaction, examination, and accommodation. ${ }^{275}$ In the accumulation phase, the jurors become aware of and acquire new knowledge and information about the law and the evidence in a trial. ${ }^{276}$ Jurors will also filter out certain information at this stage and decide it is unnecessary or irrelevant to the verdict. ${ }^{277}$ In the interaction phase, the jurors will recall information they have learned and share this information with one another; this process is influenced by communication within the group, and which jurors decide to speak. ${ }^{278}$ In the examination phase, jurors will evaluate and interpret the information they have learned during the trial. ${ }^{279}$ By highlighting certain information or presenting arguments to other jurors, individual jurors can have tremendous influence on group decisionmaking at this stage and the evaluation of information is largely impacted by the roles and status of the jurors who contribute to the deliberations. ${ }^{280}$ Because individuals with higher status often dominate group discussion, these contributions are often weighted more heavily in the jury's decision. ${ }^{281}$ Finally, in the accommodation phase, jurors integrate their various opinions to reach a verdict. ${ }^{282}$

While movement from one phase to another can be linear, it can also be recursive, with decisionmakers moving back and forth between phases. ${ }^{283}$ When jurors do not have a good idea about how to approach the task of reaching a verdict, they will spend more time on the accumulation and interaction phases where they discuss known information with one another. ${ }^{284}$ At the same time, they will spend less time on the accommodation and examination phases, where they evaluate the law and the facts they have heard during to trial in order to come to a decision. ${ }^{285}$ Giving jurors more information about their task and the

274. Straus et al., supra note 230, at 136; see also Jessica R. Mesmer-Magnus \& Leslie A. DeChurch, Information Sharing and Team Performance: A Meta-Analysis, 94 J. APPLIED PSYCHOL. 535, 543 (2009).

275. Many theorists have characterized groups as information-processing systems. Christine B. Gibson, From Knowledge Accumulation to Accommodation: Cycles of Collective Cognition in Work Groups, 22 J. ORGANIZATIONAL BEHAV. 121, 123 (2001).

276. Id. at 124 .

277. $I d$.

278. Id. at $124,126$.

279. Id. at 126 .

280. Id.

281. Id.

282. Id.

283. Id. at 127.

284. Id.

285. Id. 
various ways they can approach the decisionmaking process can increase evaluation of the evidence and improve the effectiveness of the decisionmaking process. ${ }^{286}$

Juror training in decisionmaking could be standardized and shown to jurors before they begin deliberations. One option would be technology-delivered instruction, including web-based training. ${ }^{287}$ There are various types of webbased or computer-based trainings, but one of the most popular is multimedia training, "in which text, graphics, animation, audio, and video are used through the computer to facilitate learning." 288 Studies have shown that computer-based training, especially when supplemented with training strategies, is effective in increasing user knowledge and performance. ${ }^{289}$ A recent meta-analysis of the effectiveness of web-based instruction found that it was as effective as classroom instruction and may even be more effective in some cases. ${ }^{290}$

Furthermore, when groups of people receive training as a group, not only does performance improve, but participation in the training itself increases jurors' familiarity with one another, which can also increase cohesion and improve performance. $^{291}$ Juror training will further maximize the benefits of a diverse group of individuals coming together to make an important decision about the evidence they have learned during the trial. Jury instructions that simply tell jurors to "reach an agreement" on the evidence do not provide jurors with the tools and strategies they need to thoughtfully and efficiently analyze the facts and law they learn during the trial.

Specifically, jurors would benefit tremendously from additional training in effective group decisionmaking strategies and effective group collaboration. These strategies would allow jurors to spend more time analyzing the information and law they have heard about in a trial and less time simply figuring out how to

286. Id. at 128 .

287. Aguinis \& Kraiger, supra note 6, at 463; see also Bradford S. Bell \& Steve W. J. Kozlowski, Adaptive Guidance: Enhancing Self-Regulation, Knowledge, and Performance in Technology-Based Training, 55 PERSONNEL PsYCHOL. 267, 268 (2002).

288. Michael J. Wesson \& Celile Itir Gogus, Shaking Hands With a Computer: An Examination of Two Methods of Organizational Newcomer Orientation, 90 J. APP. PSYCHOL. 1018, 1019 (2005).

289. Bell \& Kozlowski, supra note 287, at 269, 298 (discussing how supplementing technology-delivered instruction adaptive guidance —or "training strategy that provides trainees with diagnostic and interpretive information that helps them make effective learning decisions"-helps people make better learning decisions and improves performance). As the authors noted, "[i]ndividuals who received adaptive guidance displayed higher levels of basic and strategic knowledge and performance and were also better able to transfer their skills to the more complex generalization trial." Id.

290. Traci Sitzmann, The Comparative Effectiveness of Web-Based and Classroom Instruction: A Meta-Analysis, 59 PERSONNEL PsyCHOL. 623, 640 (2006) (finding that web-based instruction was six percent more effective than classroom instruction for teaching declarative knowledge, and that the two methods were equally effective for teaching procedural knowledge).

291. MORELAND ET AL., supra note 273, at 42. 
approach the information. Additionally, jurors should be trained in information sharing, which will ensure that the group discusses all relevant evidence. Information sharing can also help reduce group conformity and encourage individual jurors to mention and discuss minority views. Information sharing will further help achieve the goal of a truly diverse decisionmaking body. Finally, jurors should also be trained in effective decisionmaking procedure, including the selection of the foreperson. This process will help encourage more thoughtful evaluation of the evidence and help reduce the impact that status and social conformity has on group decisionmaking.

\section{A. Training in Decisionmaking}

Jurors should be given training in decisionmaking strategies and told to discuss those strategies before they are asked to reach a decision on the evidence they have heard during a trial. Groups often do not discuss their decisionmaking strategies, ${ }^{292}$ and juries, composed of laypeople with little or no training in legal decisionmaking, are no exception. Moreover, some research suggests that many groups never discuss strategies unless some group norm is violated. ${ }^{293}$ Furthermore, unless they are instructed to discuss decisionmaking strategies, groups are especially unlikely to do so when it would require them to make "comparisons about the relative quality of members' inputs." ${ }^{294}$ However, when groups are told to explicitly consider how they should accomplish their task, performance improves. ${ }^{295}$ As one author noted, "this is especially true when there is no generally accepted procedure for accomplishing the task and when the task demands a high degree of coordination and information exchange."296

Furthermore, groups trained in group decisionmaking and group collaboration perform better than groups without such training. In one study exhibiting the positive effects of training on group decisionmaking, researchers had subjects participate in the Moon Survival task, a problem that is used to measure group performance on decisionmaking tasks. ${ }^{297}$ It asks group members to imagine that they have crash-landed on the moon and are 200 miles from the nearest base. ${ }^{298}$ They have fifteen pieces of equipment available to help them and they are asked to rank them based on how helpful they will be as they walk to safety. ${ }^{299}$ In one

292. James R. Larson, Discussion of Shared and Unshared Information in Decision-Making Groups, 67 J. PERSONALITY \& SOC. PsYCHOL. 446, 447 (1994).

293. Rebecca A. Henry, Improving Group Judgment Accuracy: Information Sharing and Determining the Best Member, 62 Org. Behavavior \& Human Decision Processes 190, 195 (1995) (citing various studies).

294. Id.

295. Id.

296. Larson, supra note 292, at 448.

297. Preston C. Bottger \& Phillip W. Yetton, Improving Group Performance by Training in Individual Problem Solving, 72 J. APPLIED PSYCHOL. 651, 651 (1987).

298. Id.

299. Id. at 652. The "correct" answers to the problem are based on the ranks assigned to the 
study, one group of subjects were asked to solve the problem individually for ten minutes; each subject was then randomly assigned to the group and the group spent an additional thirty minutes solving the problem. ${ }^{300}$ In a second group, group members heard the problem and then were read a statement that explained possible threats to good decisionmaking. ${ }^{301}$

Subjects were told to make sure they had not misread the instructions or made unwarranted assumptions. ${ }^{302}$ They were told about the four common ways in which people make poor decisions: hypervigilence (which is characterized by "frantic searches for quick solutions"), unconflicted adherence ("decision makers ... stick with the first idea that comes into their heads, without further evaluation of its consequences"), unconflicted change (where people "change [their minds] uncritically and accept the first new idea that comes along"), and defensive avoidance (which involves delaying a decision, minimizing the importance of the problem, and ignoring nagging doubts about the decision). ${ }^{303}$ The subjects were given strategies for dealing with these common problems and asked to make their decisions about the items as a group. ${ }^{304}$ The groups that were given guidance about the effective use of information produced better solutions than the uninstructed group. ${ }^{305}$

Finally, when groups are trained in decisionmaking strategies, they plan in advance how they will work on a task, make more "information-vigilant" comments than untrained groups, and take significantly longer to reach a decision. ${ }^{306}$ One study found that teams that were given training in effective group collaboration - when the team was told to "explicitly explore[] strategies for coordinating and integrating members' work"-significantly outperformed groups that did not receive the training. ${ }^{307}$ Task performance improves with training, and if jurors receive even minimal training in decisionmaking strategies and group collaboration techniques, that training could directly influence the quality of jury decisionmaking. ${ }^{308}$

Jurors can be trained to use more effective decisionmaking strategies to reach a verdict. Jurors should be instructed to discuss how they will approach their deliberations and told about common pitfalls associated with group decisionmaking, both of which would help reduce the production losses that

objects by the Crew Equipment Research Unit at the National Aeronautics and Space Administration. Id.

300. Id. at 653 .

301. Id.

302. $I d$.

303. $I d$.

304. Id. at 653-54.

305. Id. at 654 .

306. Larson, supra note 292, at 452.

307. Anita Williams Wooley et al., Bringing in the Experts: How Team Composition and Collaborative Planning Jointly Shape Analytic Effectiveness, 39 SMALl GrouP RES. 352, 367 (2008).

308. Henry, supra note 293, at 195-96. 
commonly occur in groups. ${ }^{309}$ This training could be accomplished through webbased instruction shown to jurors before the introduction of evidence. This type of training can also help jurors recognize the various resources other jurors bring to the deliberation process. ${ }^{310}$ This training is not an attempt to turn jurors into legal experts, but is instead a way to best capture the unique viewpoints and commonsense approach individual jurors bring to group decisionmaking. Training jurors to recognize pitfalls common to all group decisionmaking, and instructing them to first discuss and then take a structured approach as they evaluate the evidence they heard during a trial can improve the process of decisionmaking and encourage a more thorough and evenhanded evaluation of the evidence.

\section{B. Training in Information Sharing}

In addition to general decisionmaking strategies, juries should be given additional training in information sharing before they begin deliberations. When juries deliberate, they do not necessarily discuss all of the relevant information and evidence they learned during the trial. Whether a particular piece of evidence is discussed by the jury depends on several things: whether jury members mention the evidence, whether jury members recall the information, whether they have the opportunity to mention the evidence, and whether they are motivated to participate in the discussion. ${ }^{311}$ The jury's task is an important one, and people are more motivated to expend energy to do their best and consider all relevant information when they believe they are engaged in an important task. ${ }^{312}$ In the group setting, however, jurors can be influenced by various group dynamics that cause them to leave the discussion to other jurors or keep silent about a particular piece of evidence because they believe it is not the majority view. Training in information sharing can help reduce these effects and encourage more thoughtful decisionmaking in jurors.

Jurors have two main sources of information available to discuss: shared information they learn during the trial and unshared information that includes individual jurors' preexisting knowledge and experiences. ${ }^{313}$ The concept of

309. Straus et al., supra note 230 , at 139.

310. Wooley et al., supra note 307 , at 367.

311. See Larson, supra note 292, at 447 (discussing Strasser \& Titus' "Information Sampling Model"); Garold Strasser \& William Titus, Pooling of Unshared Information in Group Decision Making: Biased Information Sampling During Discussion, 48 J. PERSON. Soc. PsYCHOL. 1467 (1985).

312. Id.; see also Sara Gordon, What Jurors Want to Know: Motivating Juror Cognition to Increase Legal Knowledge \& Improve Decision Making, 81 TENN. L. REV. 751 (2015). Various studies suggest that jurors do take their responsibilities very seriously and want to do a good job. See, e.g., VIDMAR \& HANS, supra note 2, at 245; Ellsworth, supra note 176, at 218.

313. See generally Strasser \& Titus, supra note 311, at 1468; see also R. Scott Tindale \& Tatsuya Kameda, 'Social Sharedness' as a Unifying Theme for Information Processing in Groups, 3 Group PROCESSES \& INTERGROUP REL. 123, 124 (2000). 
shared and unshared information distinguishes group decisionmaking from individual decisionmaking. Because they have different backgrounds and experiences, individual jury members necessarily have different information and strategies to share with one another and to use in making a decision. Furthermore, because they have different life experiences, a diverse group of jurors will have access to more familiar information - information contributed by at least one member of the group - and when the group does face unfamiliar information, a smaller part of that information will be unfamiliar to every member of the group. Diverse groups therefore have more time to identify and analyze that unfamiliar information. ${ }^{314}$

When jurors deliberate face-to-face in an unstructured environment where they are required to reach a consensus, they tend to focus on information that is shared by all members of the jury and to primarily consider the information that supports the group's existing preferences. ${ }^{315}$ Furthermore, studies suggest that jurors begin deliberations with at least an initial decision on the verdict and a goal to quickly reach a decision. ${ }^{316}$ Most studies show that in nine out of ten cases, the jury's vote on the first ballot predicts the outcome of the verdict. ${ }^{317}$ In other words, jurors are less likely to share new information or discuss alternative ideas because they have already made up their minds.

Furthermore, studies on group decisionmaking suggests "that the information group members choose to mention during discussion is significantly influenced by the information that other members have already brought out, by members' prediscussion preferences, and by status differences within the group." ${ }^{\prime 318}$ Group discussion "is rarely a systematic and balanced exploration of the relevant issues." 319 Instead, group members often do not contribute all available information and discussion is instead focused on information the group possesses collectively and information that supports the group's preexisting preferences. ${ }^{320}$ This focus on known information and preexisting preferences can in turn perpetuate biases that group members bring to the group: information bias, where group members spend most of their time discussing information already available to all members of the group, ${ }^{321}$ and preferential bias, where group members prefer alternatives they hear at the beginning of discussion, even if they would not otherwise prefer those alternatives with more information. ${ }^{322}$

Jurors should be instructed to share information and to discuss everything

314. Kristina B. Dahlin, Team Diversity and Information Use, 48 ACAD. MGMT. J. 1107, 111 (2005).

315. Straus et al., supra note 230, at 132.

316. Maria Sandys \& Ronald C. Dillehay, First-Ballot Votes, Predeliberation Dispositions, and Final Verdicts in Jury Trials, 19 LAW \& HUM. BEHAV. 175, 188 (1995).

317. Id.

318. Larson, supra note 292, at 446 (citing various studies).

319. Strasser \& Titus, supra note 311, at 1467.

320. Straus et al., supra note 230, at 132.

321. Id.

322. Id. 
they think is relevant to the verdict. This discussion can improve the quality of jury deliberations. In one study, groups who were simply told to "list the three most relevant pieces of information which come up in your discussion of each question" performed significantly better on a set of quantitative judgment questions. ${ }^{323}$ Furthermore, in newly-formed groups, strong social norms to be pleasant and non-confrontational are likely to exist, and group members may avoid speaking up to share their own impressions out of fear of violating this norm. ${ }^{324}$ If jurors are explicitly instructed to share their thoughts and impressions of the evidence, the group decision will more fully benefit from the diversity of experiences individual jurors bring to the group.

Furthermore, jurors should be instructed to discuss the evidence before they share their individual opinions about the case. If jurors withhold their individual preferences until the group has discussed all of the relevant evidence and various alternatives, information bias and preferential bias will be reduced. ${ }^{325}$ Similarly, if jurors are able to separate new idea generation from their actual decision about the evidence, jurors will be better able to "expand the number of ideas that are identified and enhance solution quality." 326

Finally, jury instructions that simply admonish jurors to discuss the evidence they heard with other jurors should be amended to explicitly recommend that each juror actively contribute both shared and unshared information to the jury deliberation. In order to reduce productivity losses, jurors could be instructed to use methods that do not require them to take turns. For example, they could write their answers down simultaneously and then take turns exchanging those ideas with the group. By encouraging jurors to present their opinions simultaneously, social conformity and confirmation bias will be reduced. ${ }^{327}$ Each juror could then be instructed to share her ideas in order to promote involvement and increase information sharing. This requirement could make jurors more accountable for their role in the deliberation process and limit social loafing by individual jurors. ${ }^{328}$ As Shestowsky \& Horowitz note, "instructions that emphasize the role that active jury discussion plays in sustaining the legal system may be one way of increasing personal responsibility and reducing social loafing in the jury context." 329

While jurors may bring diverse experiences to bear on their evaluation of the evidence they hear during a trial, this resource might not be effectively used

323. Henry, supra note 293, at 193. Examples of questions included, "(a) the year the safety pin was invented, (b) the coldest temperature ever recorded in Alabama, and (c) per capita beef consumption in the United States." Id. at 192.

324. See infra Part II.C.

325. See supra notes 311-12 and accompanying text; see also Straus et al., supra note 230, at 131.

326. Straus et al., supra note 230, at 137.

327. See supra Part III.A; see also Straus et al., supra note 230, at 137.

328. See generally Shestowsky \& Horowitz, supra note 20, at 333.

329. Id. at 334. 
without some prompting. ${ }^{330}$ Jurors should be reminded that different members of the group may have different perspectives on the evidence and should be encouraged to consider those perspectives in reaching a group decision. And while this training does not need to be extensive, even simple instructions to share and discuss all information can help maximize the benefits of the jury's diversity, which in turn will lead to more thoughtful and effective group decisionmaking.

\section{Training in Procedure}

Like decisionmaking strategies and information sharing, the jury's decisionmaking procedure can have a significant impact on its decision and juries should be given training in effective procedural approaches. ${ }^{331}$ Research on juries has identified two styles of deliberation: the "verdict-driven" style, where jurors conduct a public ballot before any deliberation, and the "evidence" driven style, where jurors first deliberate before voting. ${ }^{332}$ Many scholars believe that in as many as ninety percent of juries, this first vote predicts the jury's ultimate decision. ${ }^{333}$ The foreperson often decides which style of deliberation the jury will take ${ }^{334}$ and controls speaking time and the order in which other jurors participate. $^{335}$ Additionally, the order and form of initial juror opinions can influence the votes of other jurors. Some widely used group voting procedures

330. Henry, supra note 293, at 191.

331. See supra note 231 and accompanying text.

332. HASTIE ET AL., supra note 51, at 163. The "verdict-driven" style has four distinctive features: "Deliberation begins with a public ballot. Individual jurors advocate only one verdict position at a time. Evidence is cited in support of a specific verdict position. And the content of deliberation contains many statements of verdict preferences and frequent pollings." Id. In contrast, the "evidence-driven" style has the following characteristics:

Public balloting occurs only late in deliberation, and in extreme cases, only one ballot is taken to validate that a quorum has been reached. Individual jurors are not closely associated with verdict preferences but may cite testimony or instructions with reference to several verdicts. The evidence is reviewed without reference to the verdict categories, in an effort to agree upon the single most credible story that summarizes the events at the time of the alleged crime. And the early parts of deliberation are focused on the story construction and the review of evidence; not until toward the conclusion of deliberation does discussion emphasize the task of verdict classification.

Id.

333. Id. at 66 (finding a ninety-one percent accuracy rate of predilberation distribution of juror verdict preferences and the final verdict when guilty versus not guilty outcomes are the only consideration); see also Sandys \& Dillehay, supra note 316, at 188 (finding "guilty votes on the first ballot predicted final verdicts in $89 \%$ of the cases"). As Kalven \& Zeisel, in their pioneering book The American Jury, put it, "the deliberation process might well be likened to what the developer does for an exposed film: it brings out the picture, but the outcome is predetermined."

HARry Kalven, JR. \& HANS ZeISEl, THE AMERICAN JuRY 489 (1971).

334. Devine et al., supra note 19, at 699.

335. Ellison \& Munro, supra note 179, at 88. 
are the straw poll, in which jurors vote orally or by show of hands, and the rollcall vote, in which jurors individually voice their initial votes. ${ }^{336}$ In one study of mock jurors, the sequence of initial straw votes had a significant impact on later voters: in groups of six mock jurors, the fourth person to vote was heavily influenced by the previous three votes, especially when those three votes were for a guilty verdict. ${ }^{337}$

Moreover, the timing of jury votes has a significant impact on decisionmaking. In the straw-poll study noted above, the fourth-voting jurors who initially believed the defendant was not guilty were very susceptible to early straw polls with three previous guilty votes, but they were not influenced when the straw poll came later in deliberations. ${ }^{338}$ In contrast, jurors inclined to vote guilty were about as susceptible to three non-guilty votes but were even more susceptible when the poll took place later in the deliberations. ${ }^{339}$ The authors attribute this difference at least partially to the leniency bias, the "socially (and legally) preferred error of acquitting the guilty in contrast to convicting the innocent." ${ }^{340}$ When votes come after discussion, discussion increases the salience of social norms like the leniency bias. ${ }^{341}$

Jurors should be instructed to use an evidence-driven approach. Studies have found that evidence-driven juries reviewed testimony more thoroughly and considered more carefully the connections between the testimony and the applicable law. ${ }^{342}$ In contrast, verdict-driven juries spent less time reaching a decision $^{343}$ and report themselves and other jurors as less open-minded than juries who use an evidence-driven approach. ${ }^{344}$ Furthermore, to minimize the impact of status and social conformity, jurors could be instructed to avoid straw-polls and instead submit anonymous written ballots, which could be collected and relayed to the jury by the foreperson.

Finally, jurors could be instructed to think more carefully about the selection of the foreperson. Specifically, jurors could be told about how the foreperson is typically selected and told about the significant role the foreperson will play in their deliberation. The foreperson could also be responsible for making sure each juror speaks before deliberations begin and for focusing jurors' attention on the

336. James H. Davis et al., Some Social Mechanics of Group Decision Making: The Distribution of Opinion, Polling Sequence, and Implications for Consensus, 57 J. PERSONALITY \& SOC. PSYCHOL. 1000, 1000 (1989).

337. Id.

338. James H. Davis et al., Effects of Straw Polls on Group Decision Making: Sequential Voting Pattern, Timing, and Local Majorities, 55 J. Personality \& Soc. Psychol. 918, 921 (1988).

339. $I d$.

340. $I d$. at 918 .

341. Id. at 920; see also infra Part II.C.

342. HASTIE ET AL., supra note 51, at 165.

343. Id. Verdict-driven juries reach a verdict in an average of eighty-three minutes, while evidence-driven juries deliberate for an average of 131 minutes. Id.

344. Id. 
process of deliberations, rather than the ultimate verdict. Studies have found that leaders who encouraged open discussion and focused on the process of decisionmaking produced better decisions than those leaders who focused on the substance of the decisions. ${ }^{345}$ This same leadership style can be incorporated by the jury foreperson in order to enhance individual juror participation and improve the evaluation of evidence by all jury members.

\section{CONCLUSION}

One benefit of asking juries to decide verdicts is that the diverse range of experiences and knowledge in the group should lead to more informed decisionmaking. Representative juries composed of laypeople with different backgrounds and experiences promote accurate fact-finding because such a group is likely to hold diverse perspectives on the evidence, engage in more thorough debate, and more closely evaluate the facts. At the same time, a variety of problems are associated with group decisionmaking, from loss of motivation in groups due to social loafing and the free-rider effect, to the vulnerability of groups to various cognitive biases and errors. Group dynamics also play a role; it can be difficult for an individual to stand up to the group when her opinion is in the minority or when she believes that she has a lower social status than others in the group.

While jurors may bring diverse experiences to bear on their evaluation of the evidence they hear during a trial, this resource could be better captured if jurors were given training on group collaboration and group decisionmaking. Although extensive training is not realistic given the time constraints of a typical trial, even simple training in group decisionmaking, group collaboration, and effective procedures can dramatically improve performance. Jurors should be trained in effective group decisionmaking strategies to ensure thorough discussion of relevant ideas and information. Furthermore, jurors should be given strategies to reduce the tendency for information to be lost and for non-shared information to remain hidden during deliberations. Finally, jurors should be trained on effective and efficient deliberation procedures to encourage deliberation, maximize participation, and reduce social conformity. This training will further maximize the benefits of a diverse group of individuals coming together to make an important decision about the evidence and the facts they learned during the trial. 
